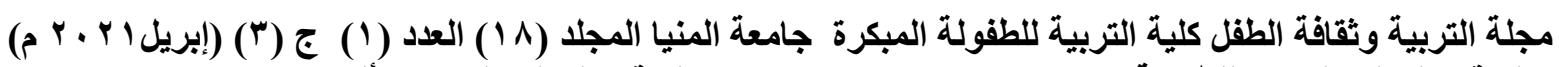

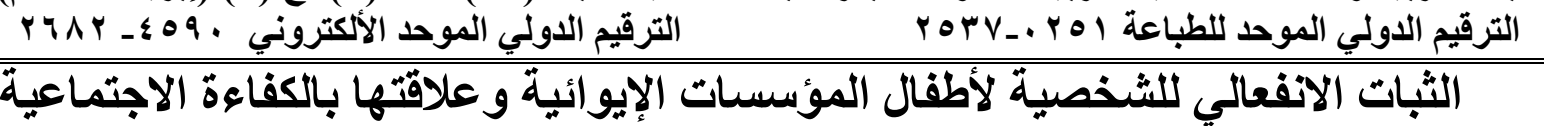

$$
\begin{aligned}
& \text { إعداد: } \\
& \text { أ/ أمنه مجدي سيد' } \\
& \text { إشر اف: } \\
& \text { أ.د/ نبيل السيد حسن }
\end{aligned}
$$

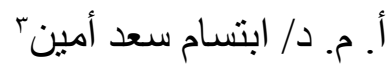

استهدف البحث الكثف عن العلاقة الارتباطية للثبات الانفعالي كأحد سمات الثخصية و الكفاءة

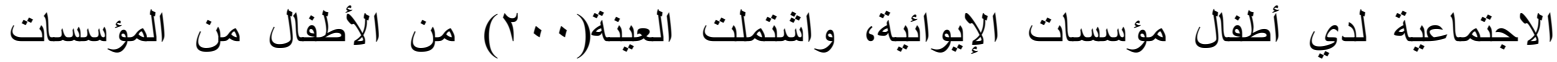
الإيو ائية،ممن ثتراوح أعمار هم بين(7: §) سنوات، وقد تم استخدام المنهج الوصفي الارتباطي لمانئمته لطبيعة البحث الحالي، ولجمع البيانات استخدمت الباحثة مقياس الثبات الإنفعالي للثخصية المصور ومقياس الكفاءة الاجتماعية وتوصلت نتائج الدراسة إلى جود علاقة ارتباطيه طردية دالة إحصائياً بين الثبات الانفعالي وكل من الابعاد التالية للكفاءة الاجتماعية: المهار ات الاجتماعية، المبادرة التفاعلية، إدارة الذات، حل المشكلات الاجتماعية والدرجة الكلية للكفاءة الاجتماعية لدي أطفال مؤسسات الايو اء،عدم وجود فروق جوهرية ذات دلالة إحصائية في الثبات الانفعالي للي أطفال مؤسسات الإيواء(مجهولي النسب - الأيتام - من كان و الديه محبوسين).

\title{
الكلمات المقتاحبة.
}

الثبات الإنفعالي، المؤسسات الإيوائية، الكفاعة الاجتماعية.

باحثة بقسم علم النفس تخصص التربية الخاصة_ كلية التربية للطفولة المبكرة- جامعة المنيا

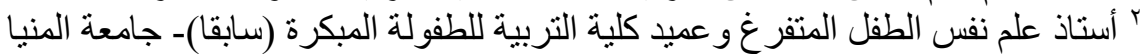
ץ أستاذ علم نفس الطفل (المساعد) بقسم العلوم النفسيةـ كلية التربية للطفولة المبكرة- جامعة المنيا 


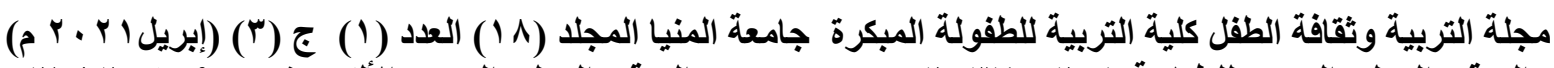

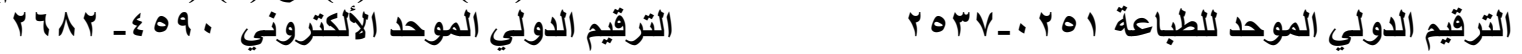




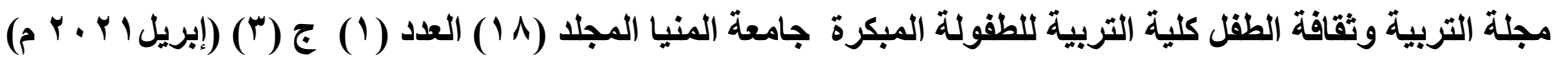

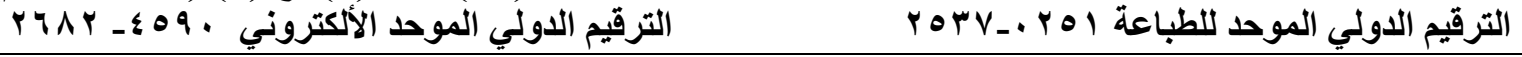

\section{Personality Emotional Stability of Children in Residential Institutions and Its Relationships to Social Competence}

\section{By:}

Amena Magdy Sayed ${ }^{1}$

Prof/ Dr. Nabil El Said Hassan ${ }^{2}$

Asst./Prof. Ibtisam Saad Amin ${ }^{3}$

\section{Abstract:}

The research aimed at revealing the correlative relationship of emotional stability as one of the personality traits and the social competence of children in residential institutions. The research sample comprised(200) children from residential institutions whose ages ranged from(4:6)years ‘the researcher utilized the descriptive research approach as it is the most suitable one for the research nature. For data collection, the researcher utilized the pictures emotional stability scale and the social competence scale Results revealed that there was a statistically significant positive correlative relationship between emotional stability and social competence dimensions of social skills, interactive initiative, self-management, solving social problems, and the total degree of social competence among children in residential institutions. Besides, there were no statistically significant differences in the emotional stability among children in residential institutions(unknown parentage - orphans - whose parents were imprisoned).

\section{Keywords:}

emotional stability, social competence, children of residential institutions

${ }^{1}$ A researcher, Department of Child Psychology, Special Education Specialization, College of Education for Early Childhood, Minia University.

${ }^{2}$ Professor of Child Psychology Emeritus and the Former Dean of College of Education for Early Childhood, Minia University.

${ }^{3}$ Assistant Professor of Child Psychology College of Education for Early Childhood, Minia University 


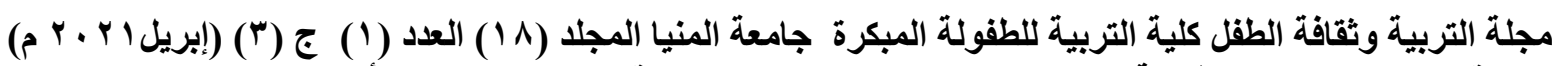

تُعتبر مرحلة الطفولة من أهم مر احل نمو الإنسان وهي فترة تكوينية، حيث تتكون فيها شخصية الطفل

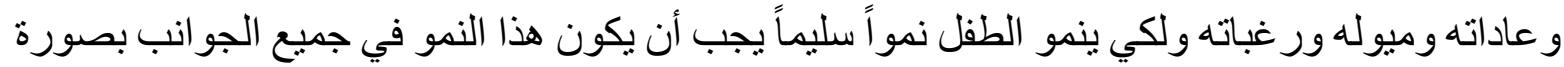

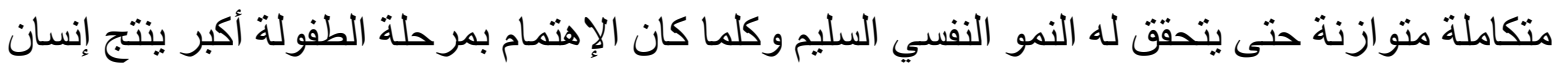

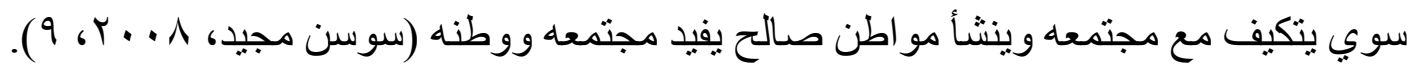

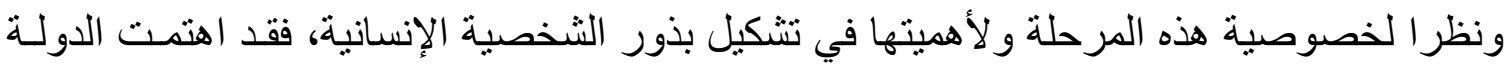

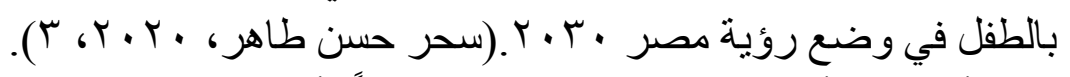

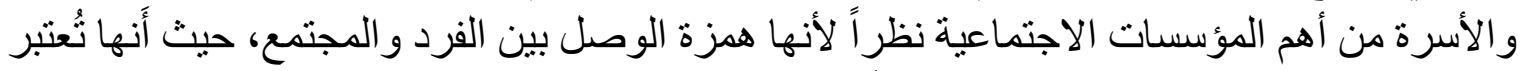

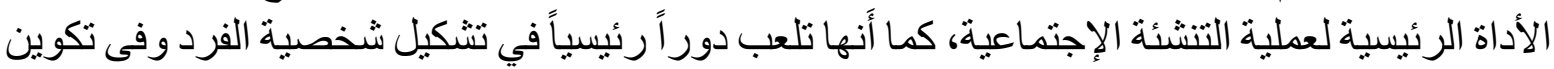

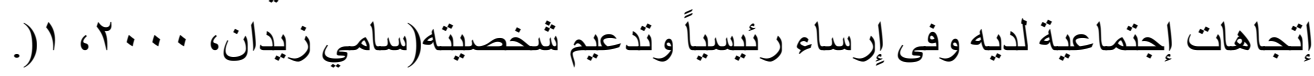

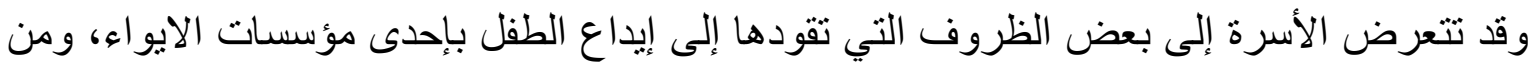

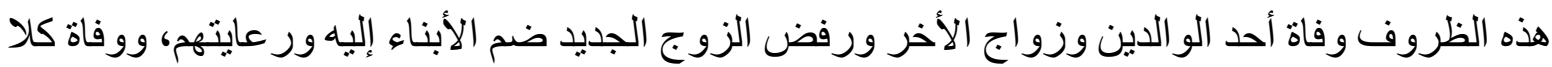

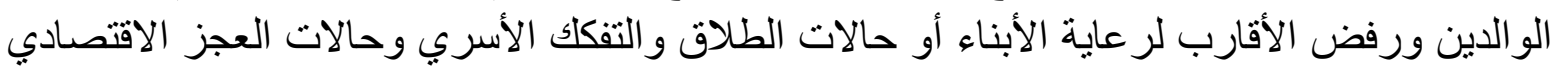

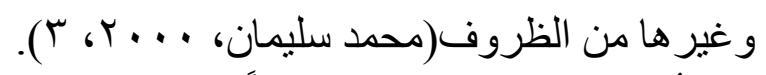

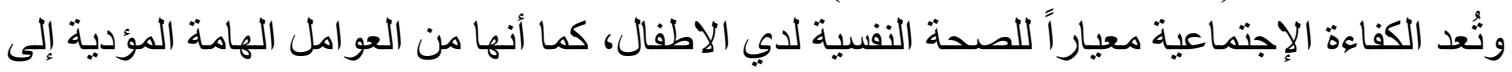

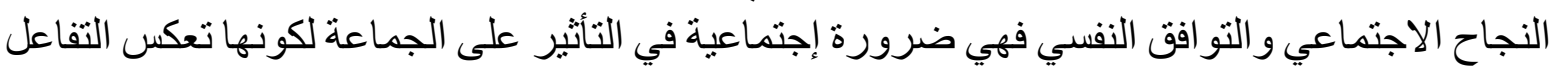

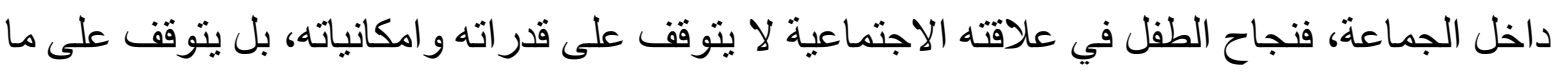

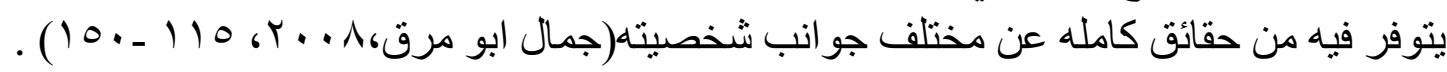

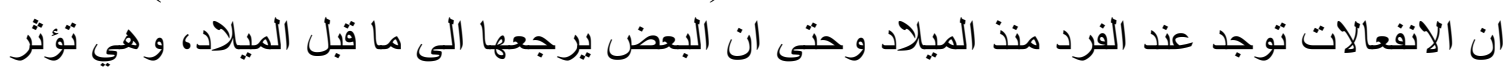

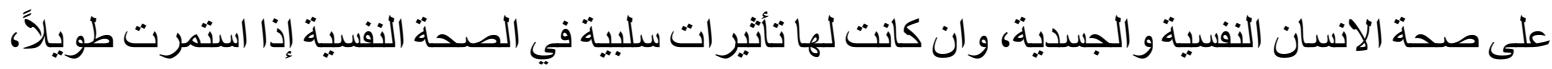

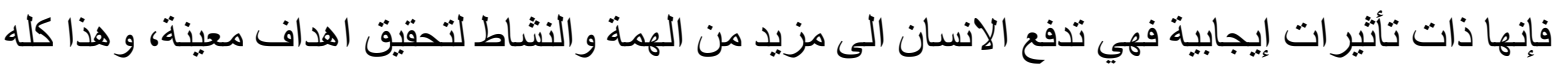

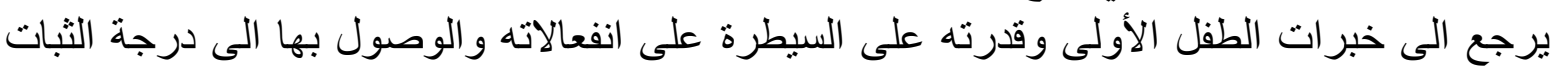

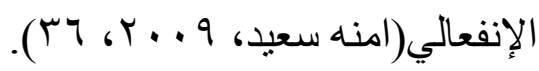
حيث إن الطفل يتأثر في نموه الانفعالي و الاجتماعي بالأفر اد الذين يتفاعل معهم وبالمجتمع القائم الذي

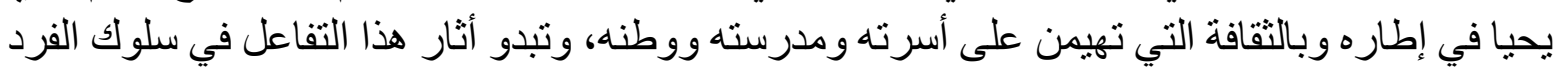

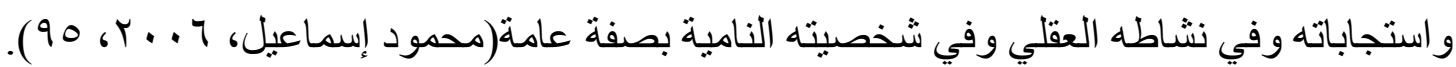

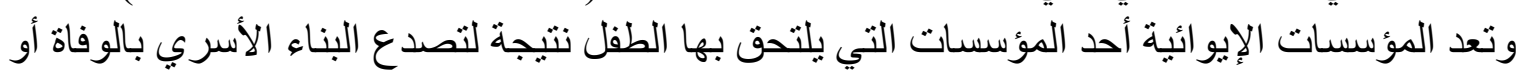

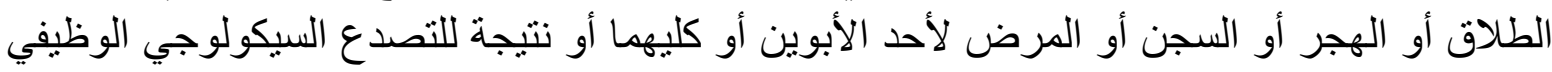

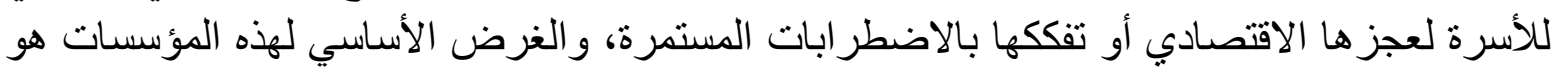

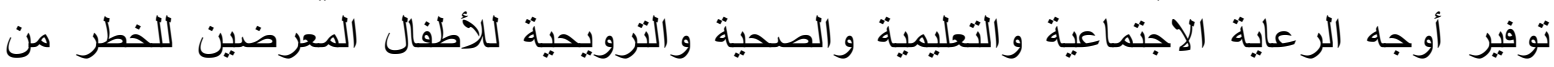

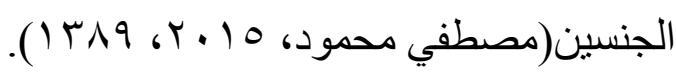




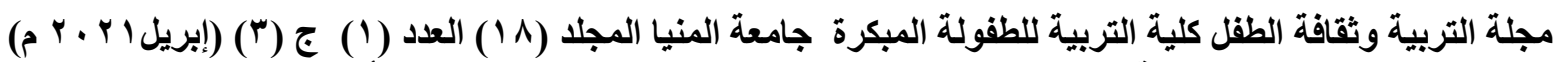

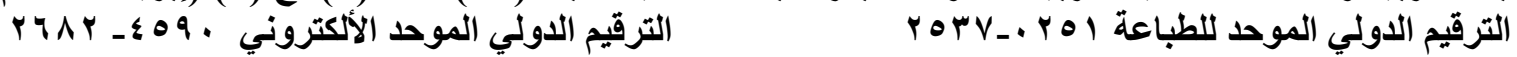

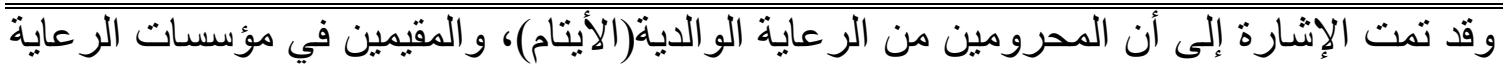

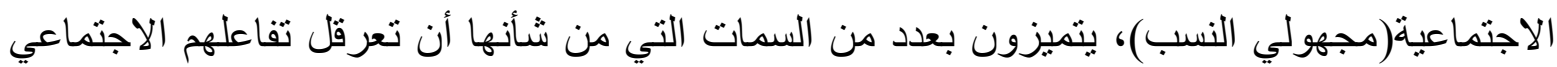

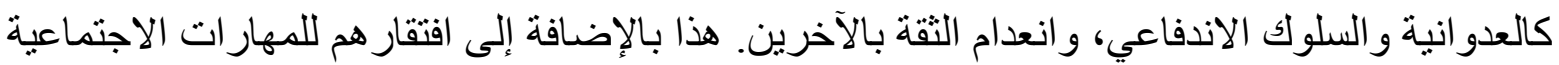

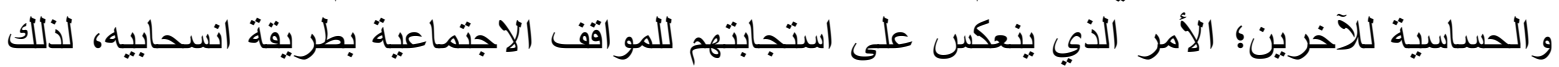

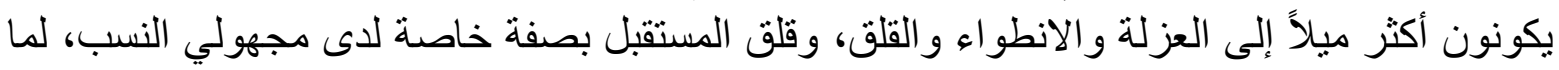

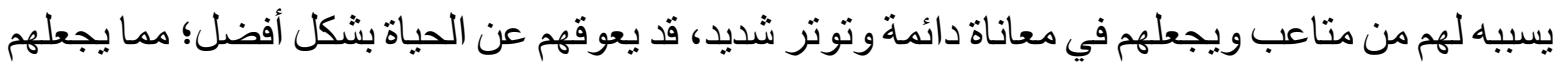

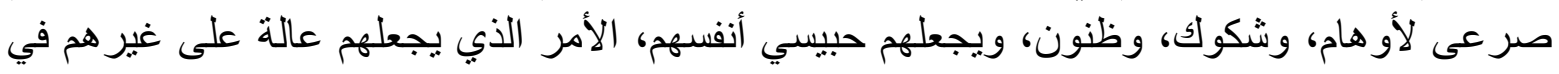

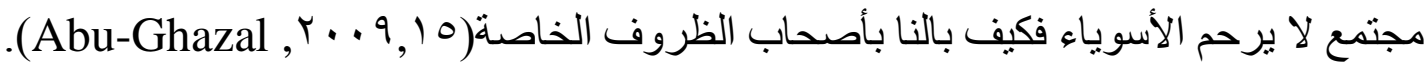

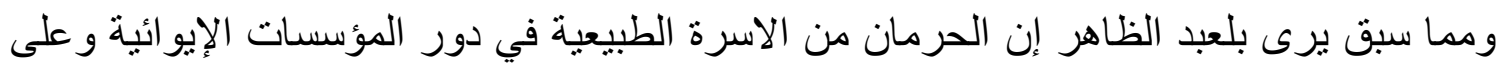

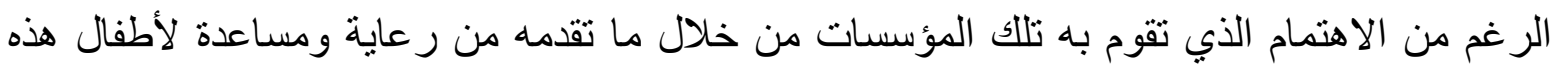

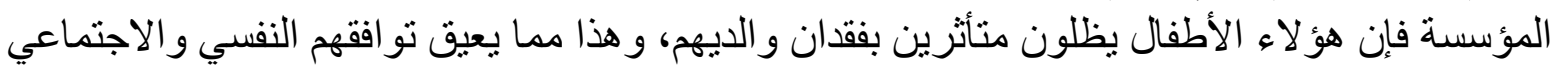

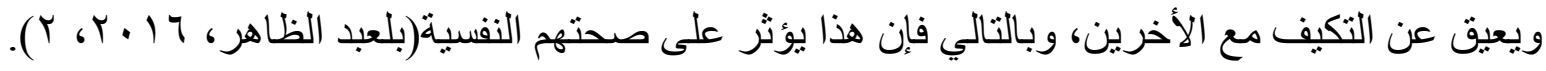

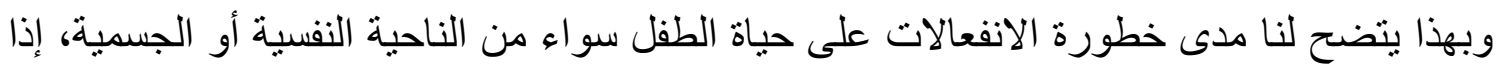

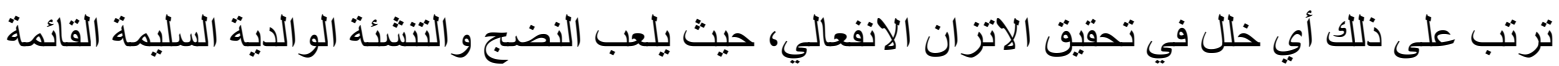

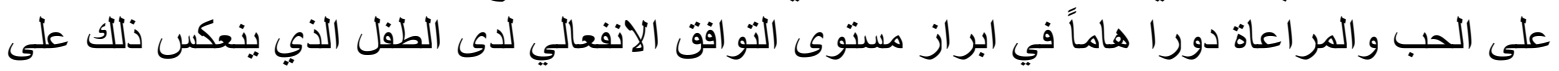

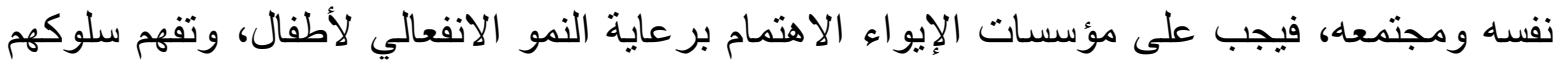

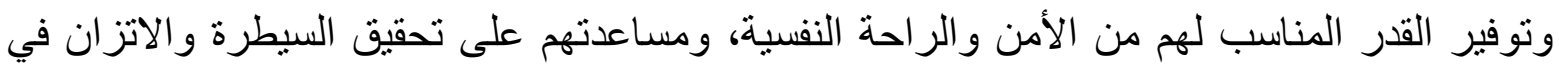

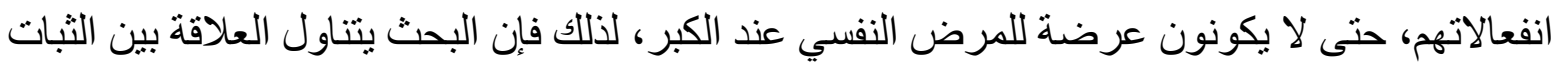

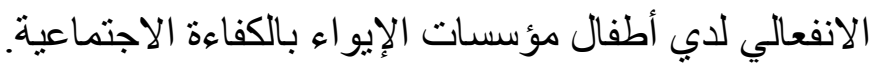

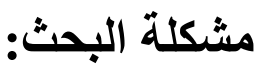

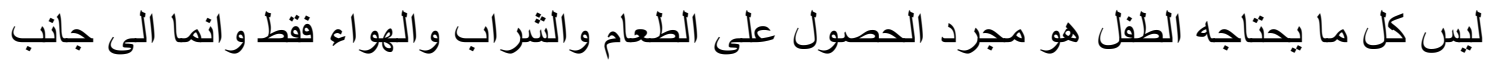

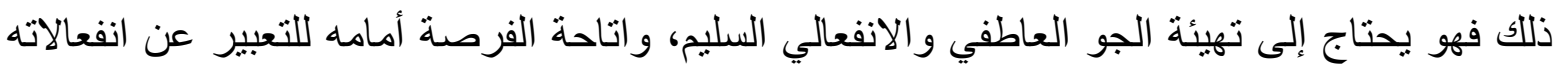

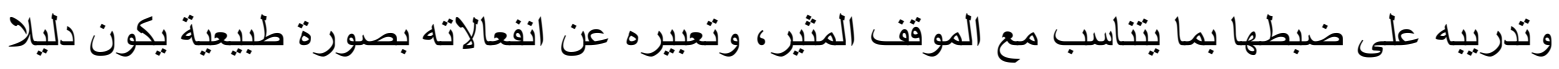

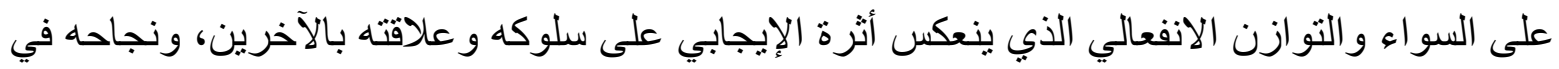

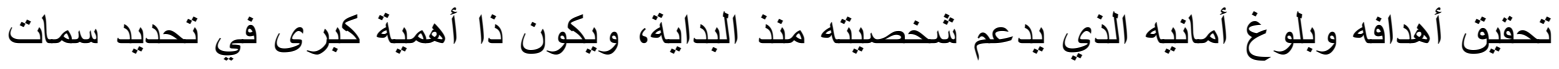

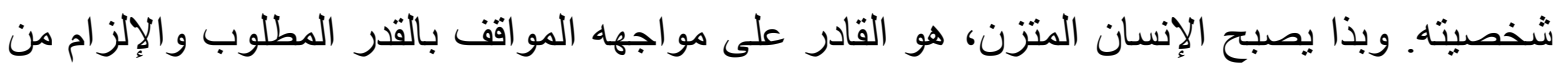

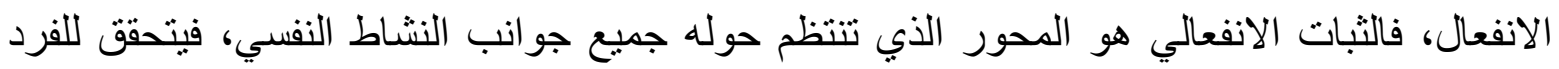

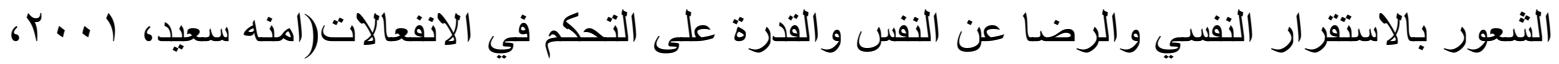

ويُعد أطفال المؤسسات الإيوائية دن الفئات المهمة التي يجب أن يتم دراستها حيث يعاني هؤلاء

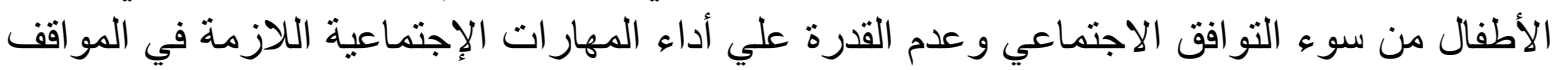

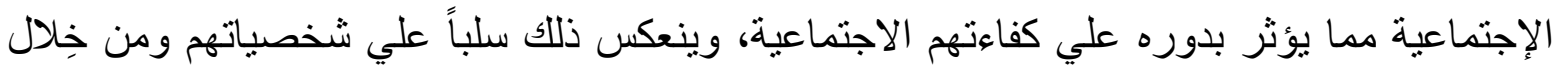




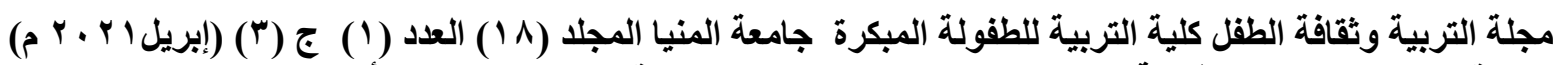

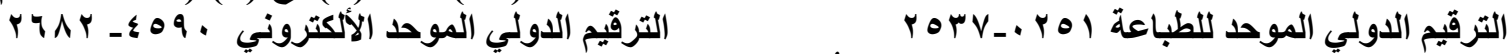

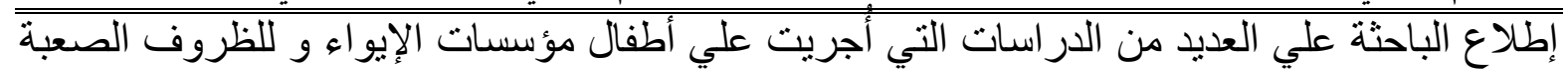

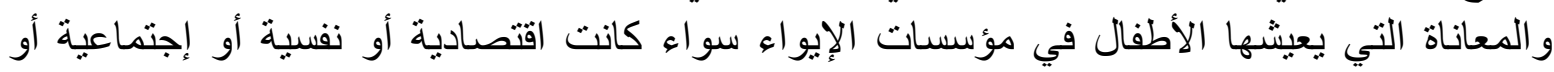

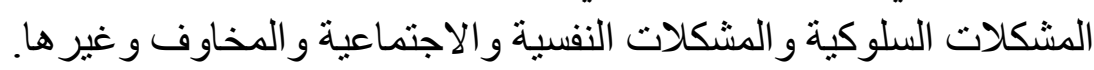

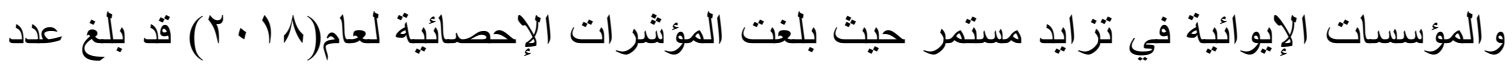

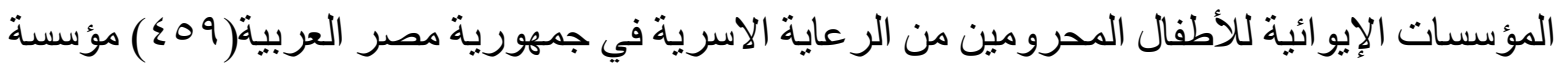

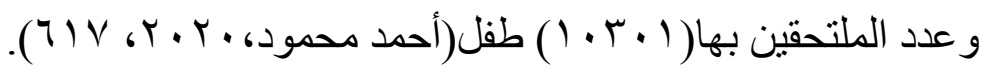

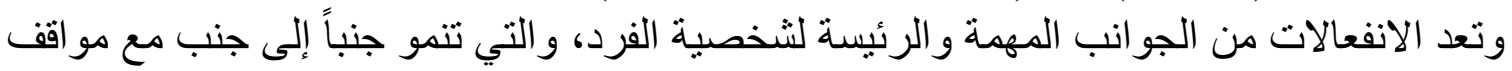

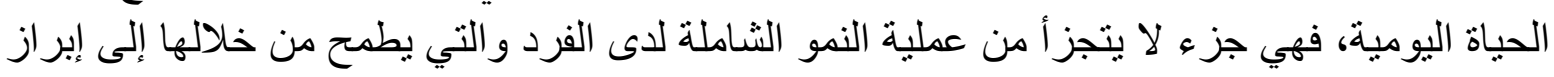

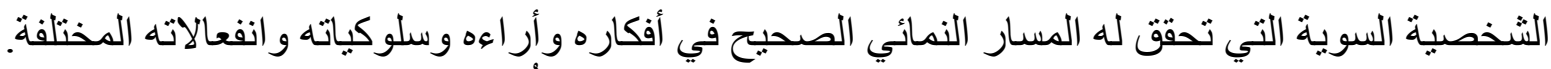

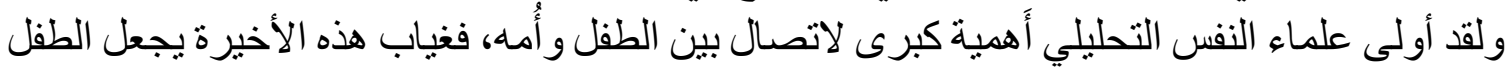

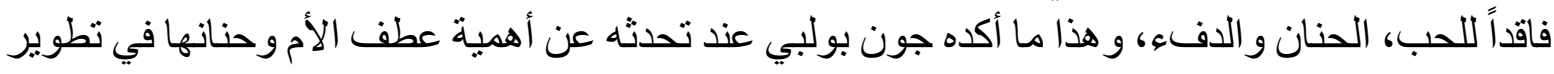

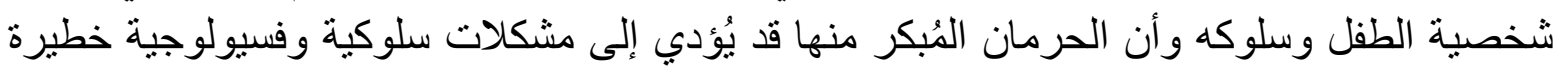

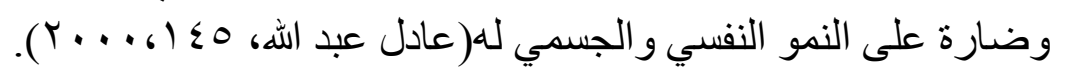

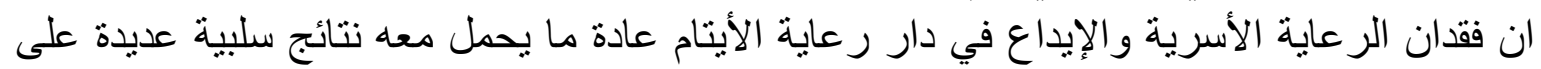

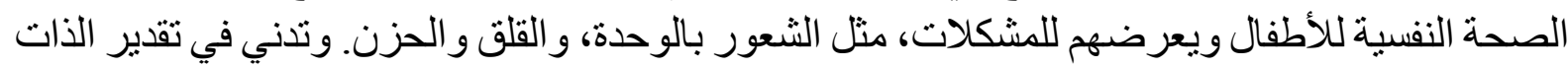

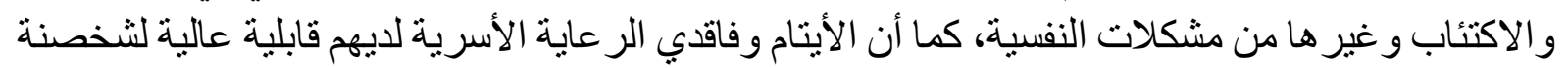

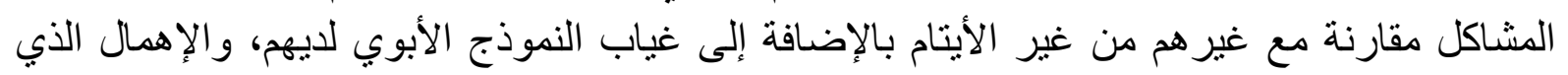

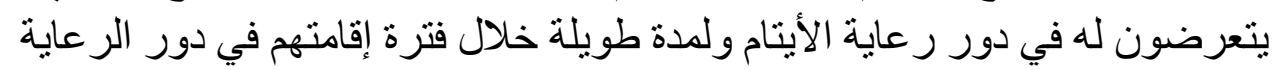

(Foster,G.and Williamson, 2000, 275-284 ). ويمكن القول بان إيداع الطفل في المؤسسات الإيوائية قد تنعكس سلبيا وتؤثر على السمات الثخصية

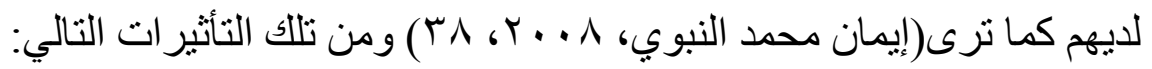

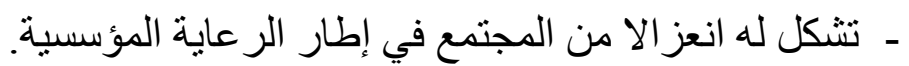

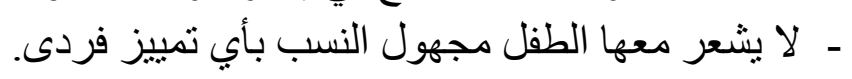
- - لا يشعر خلالها بالحميمة. - - يهيب مجهول النسب و اليتيم من الناس.

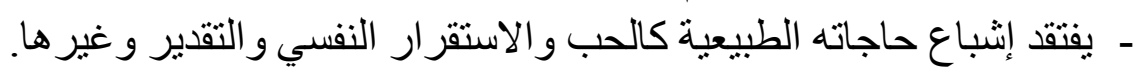

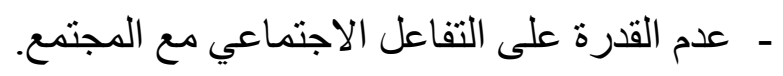
- ـ عدم الخصوصية والذي يؤثر في شخصية الفرد فلا أحد يسأله عند الطعام أو اللبس.

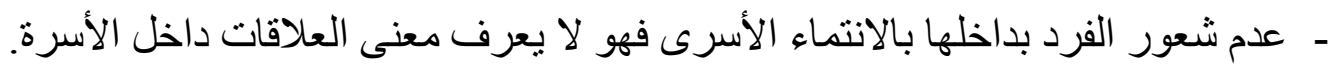

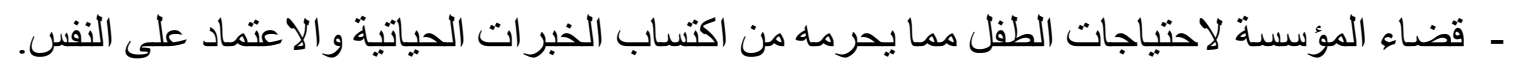

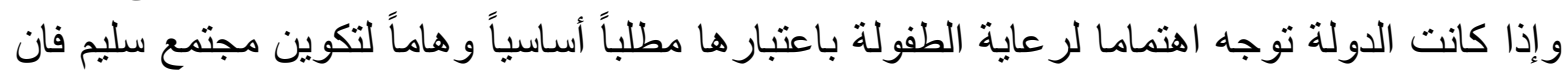

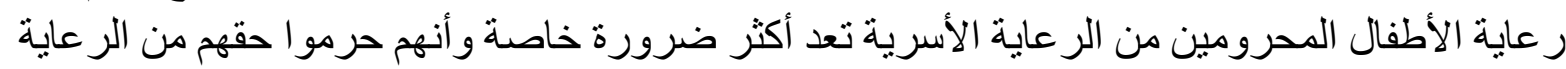




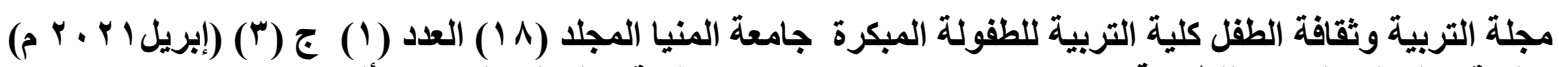

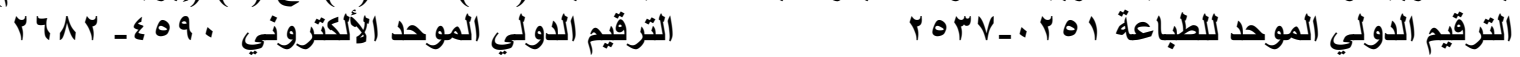

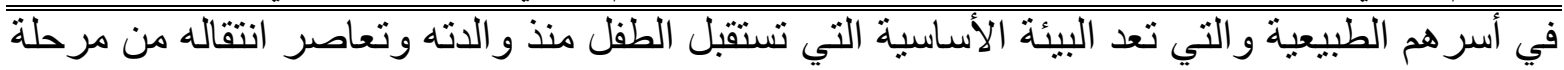

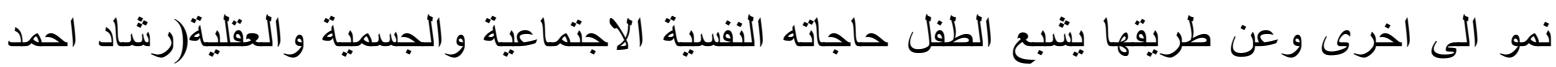

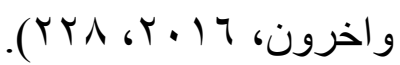

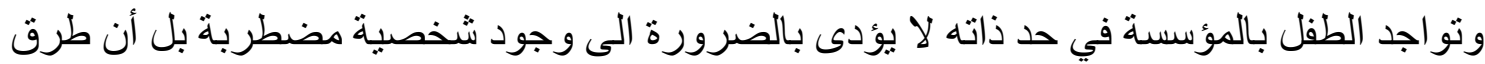

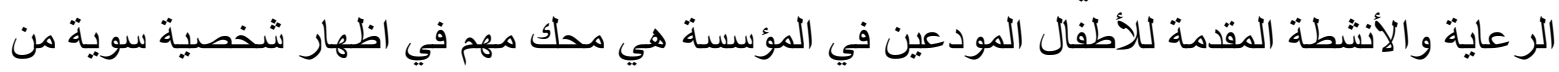

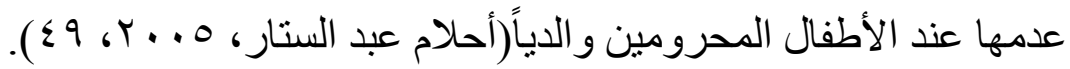

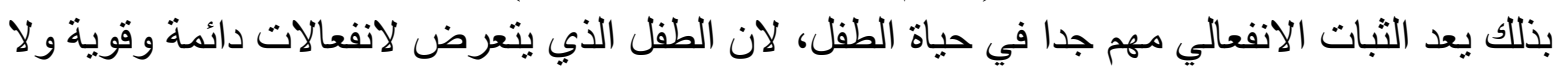

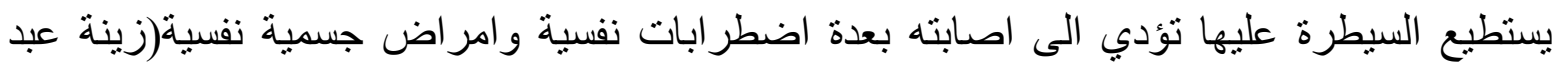

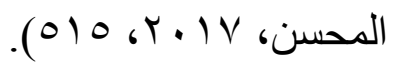

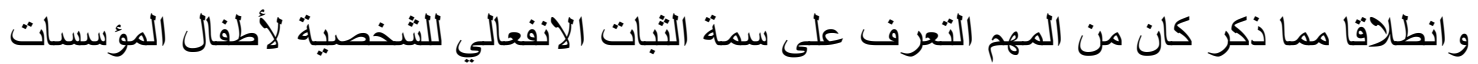

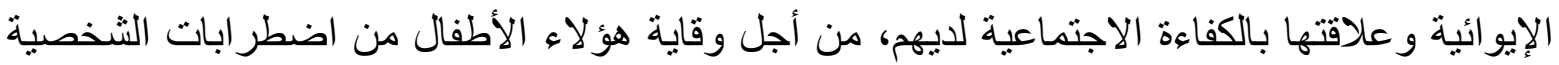

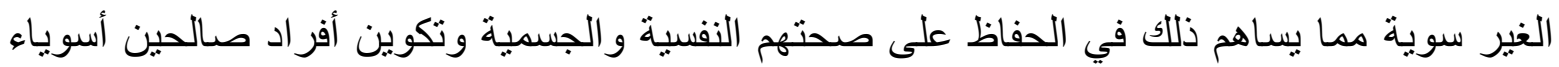

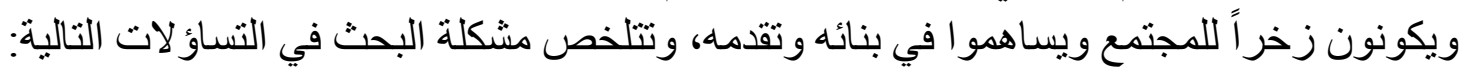

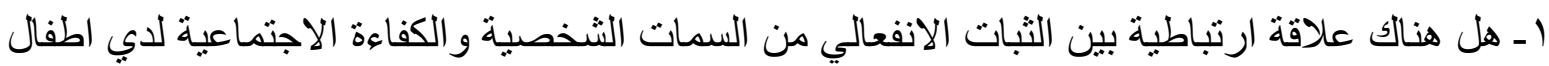

$$
\text { مؤسسات الايو اء؟ }
$$

r- هل هناك علاقة ارتباطية بين أطفال مؤسسات الإبواء(مجهولي النسب ـ الأيتام - من كان و الديه

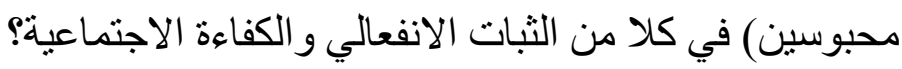

هدفا البحث: محن: هدف البحث إلى التعرف على: - الكثف عن العلاقة الارتباطية بين الثبات الانفعالي و الكفاءة الاجتماعية لدي أطفال مؤسسات الايواء. - الكثف عن العلاقة الارتباطية بين أطفال مؤسسات الإيواء(مجهولي النسب ـ الأيتام - من كان و الديه محبوسين) في كلا من الثبات الانفعالي و الكفاءة الاجتماعية.

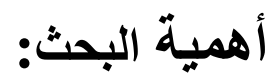 أولا:الأهمية النظرية: الهمبة}

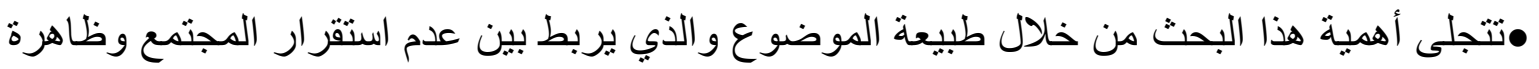

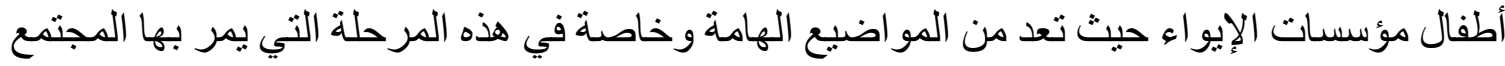

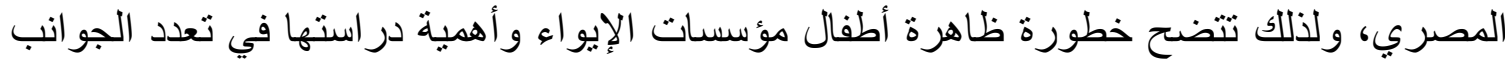
المرتبطة بها.

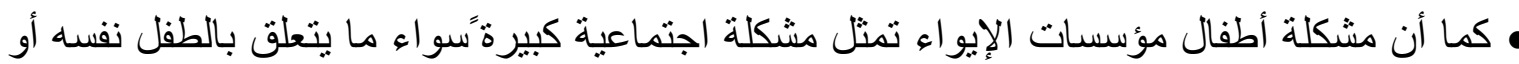

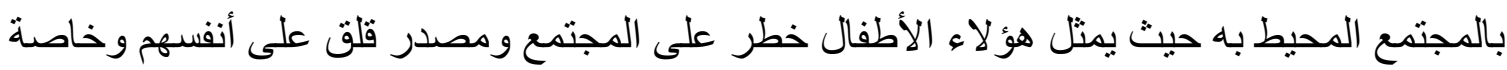




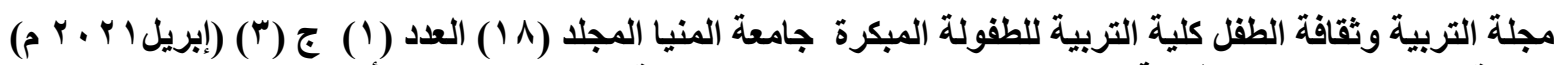

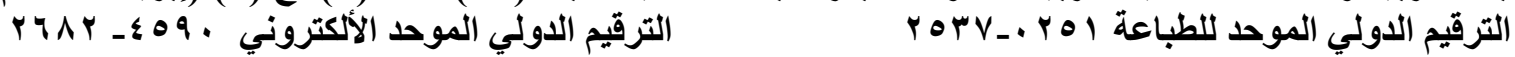

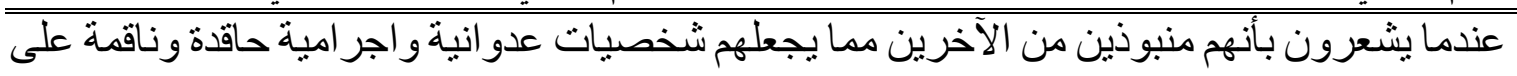
المجتمع ولذلك كانت أهمية در اسة هؤ لاء لاء الأطفال. ثانياً:الأهمية التطبيقية: •ترجع أهمية هذا البحث من الاهتمام العالمي بهذه النوعية من الأطفال وضرورة عمل دراسات

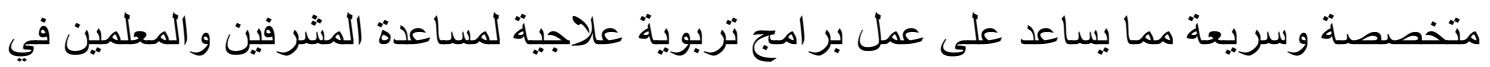
تعديل سلوكهم .

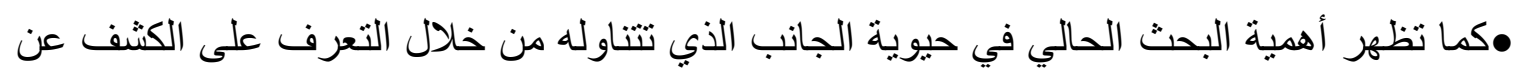

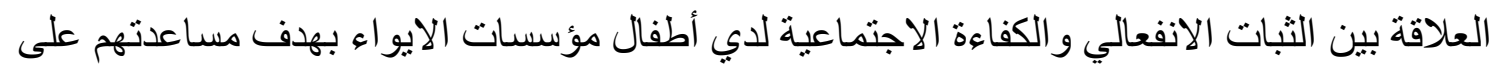
تحقيق التو افق النفسي الذي يساعدهم على اشباع حاجاتهم النفسية. حدود البحث: الحدود البشرية: البش:

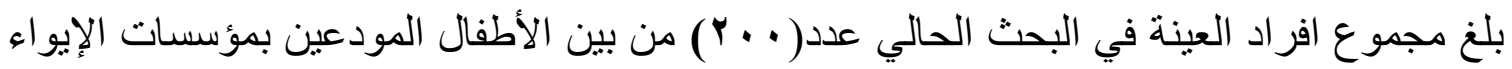

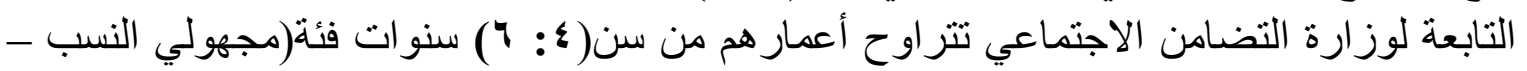

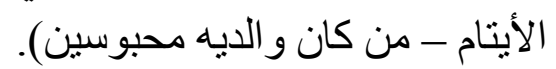

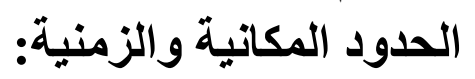

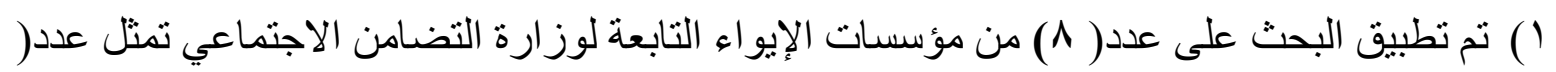

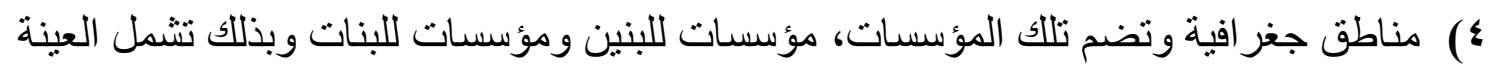

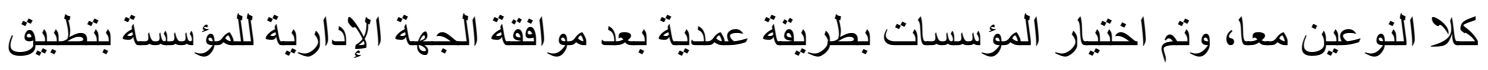

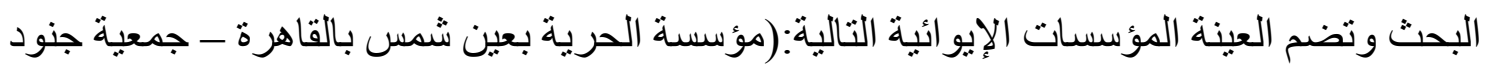

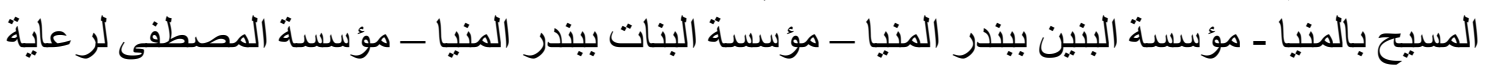
الايتام للبنين و البنات بسمالوط - مؤسسة النشاط الروحي للأيتام بسمالوط ـ - جمعية السلام القبطية بملوى - جمعية سيدات ماري مرقس بملوى).

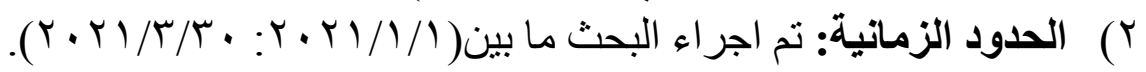
الحدود الموضوعية: تناول البحث عدد من الموضو عات تمثنو الثبات الانفعالي، أطفال المؤسسات الإيو ائية، الكفاءة الإجتماعية.

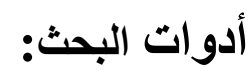
استخدمت الباحثة الأدو ات التالية: - مقياس السمات الثخصية المصور (إعداد الباحثة). - مقياس الكفاءة الاجتماعية(إعداد مروة مر اد حسني، ع ( ـ ب). 


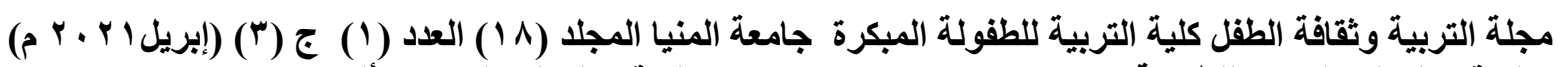

الثبات الانفعالي:يعرف الثبات الإنفعالي بانه القدرة على التخلص من تباينات الانفعالات الثائعة في

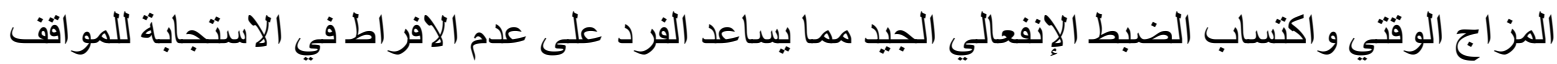

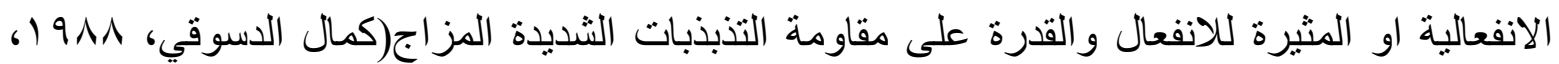
. ( $\sum V T$

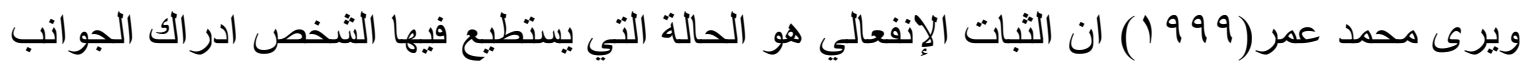

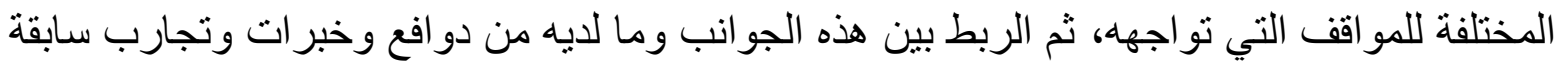

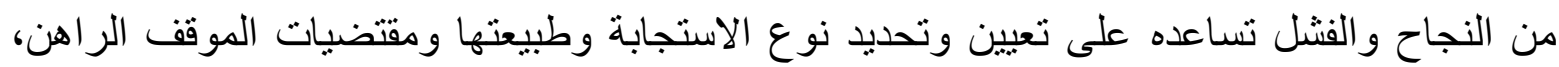

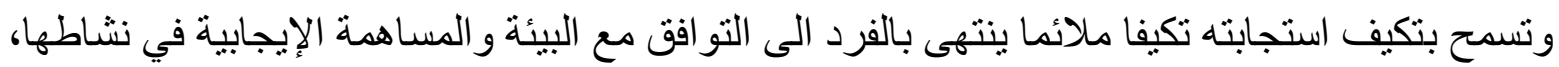

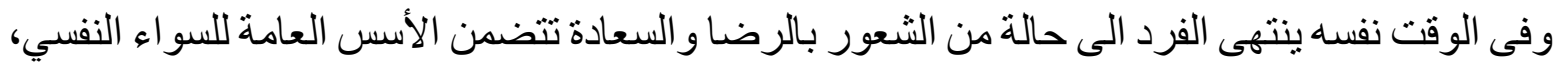

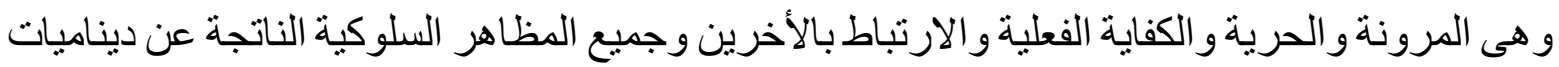

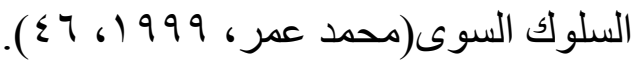

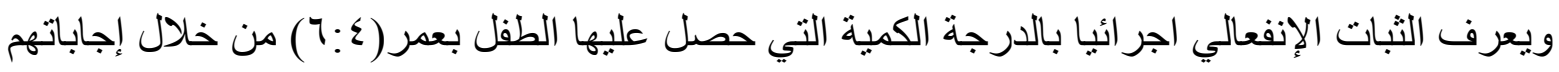

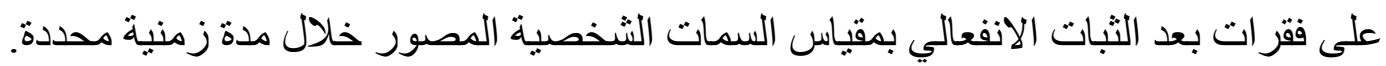
الكفاعة الاجتماعية:

يعرف والش وبيرمان(Welsh J. \& Bier man K., 2000, 3:6) الكفاءة الإجتماعية بأنها "المهارات الاجتماعية والوجدانية والمعرفية والسلوكيات التي يحتاج الإفراد إليها من أجل تكيفهر

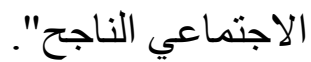

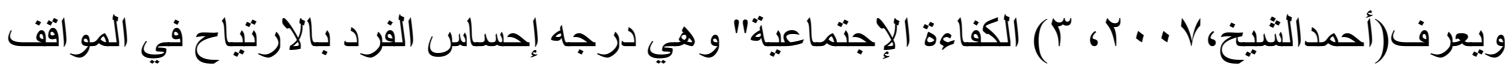

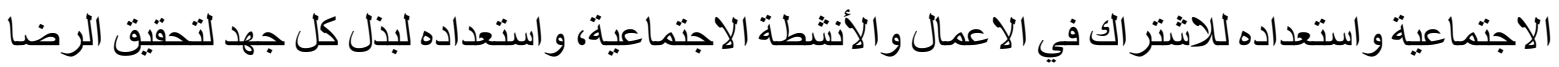

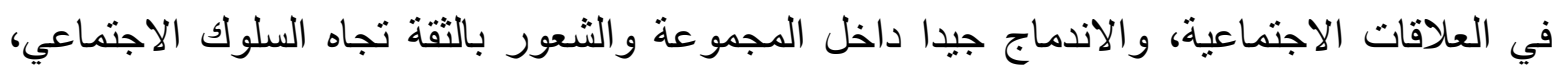

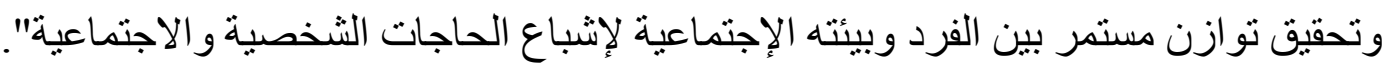

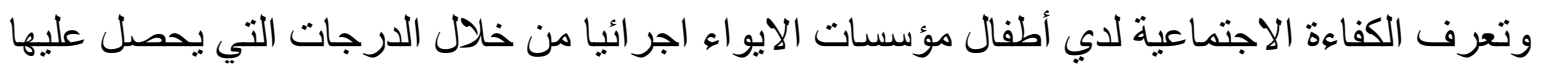
الطفل في مقياس الكفاءة الاجتماعية الموجود في البحث الكفئ الحالي. المؤسسات الإيوائية:

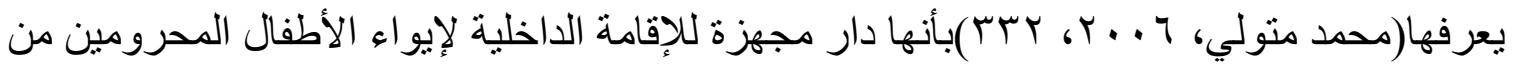

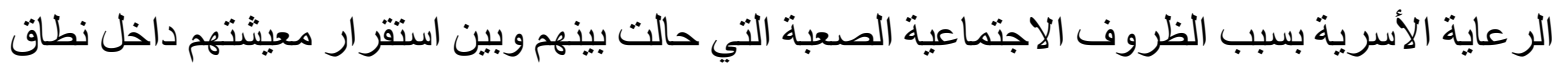

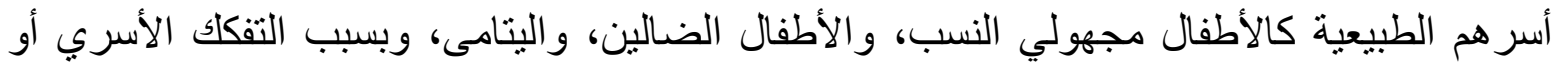
المرض أو عجز أحد الأبوين. 


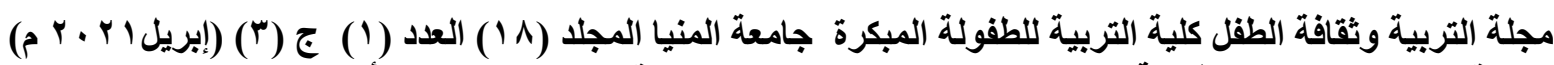

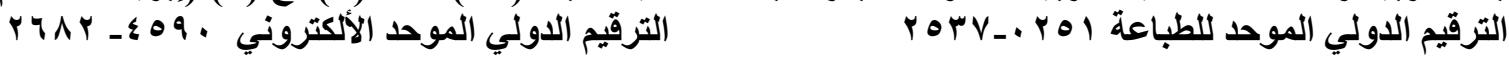

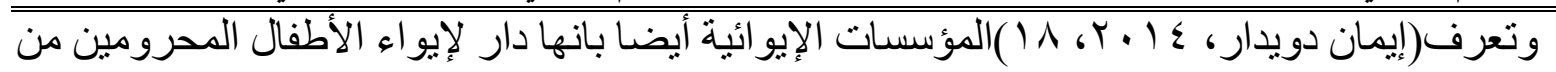

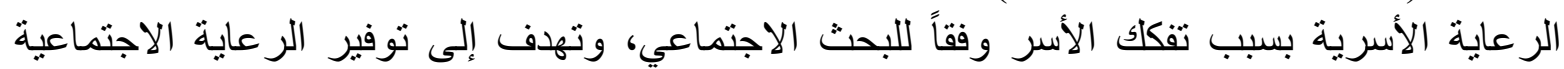
و التعليمية والصحية و المهنية و الدينية و الترويحية لتهية للأطفال. وتعرف مؤسسات الايو اء اجر ائياً كماورد بالائائحة النموذجية للمؤسسات الإيو ائية للأطفال هي دار إيو ائية

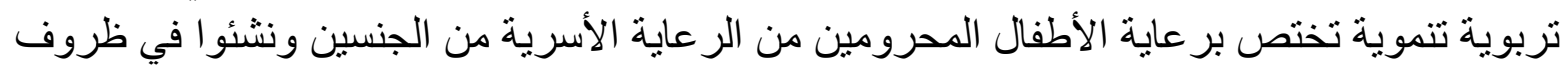

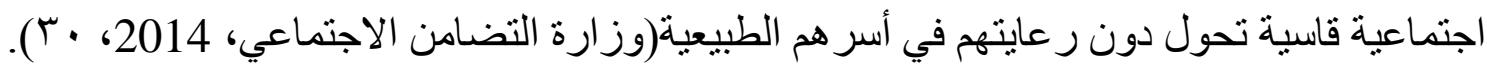

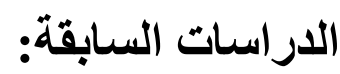

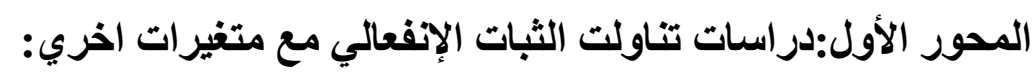

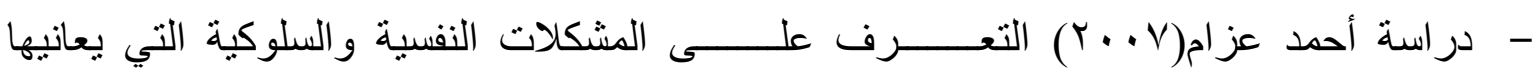

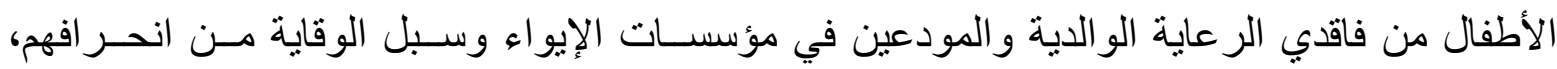

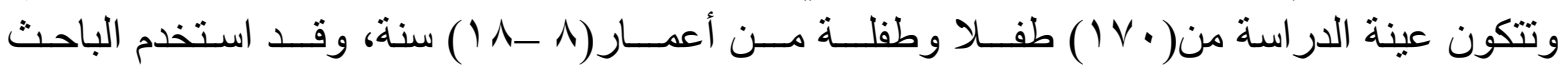

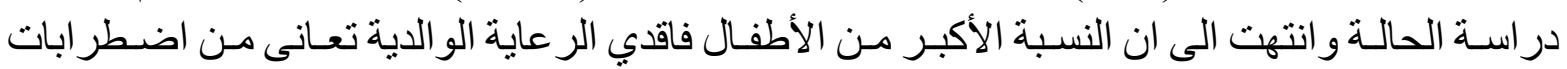

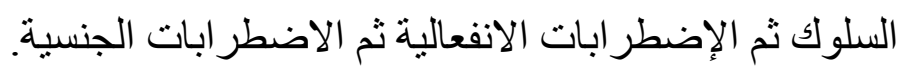

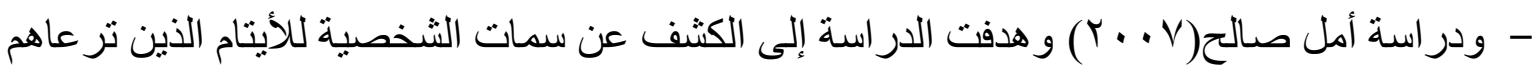

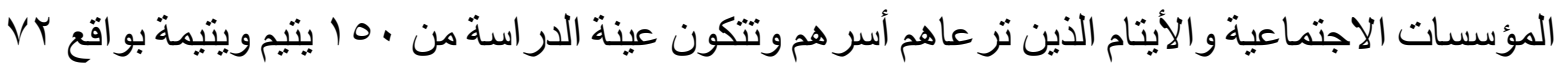

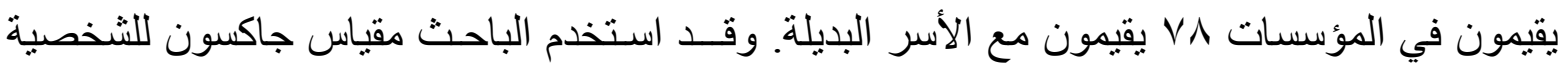

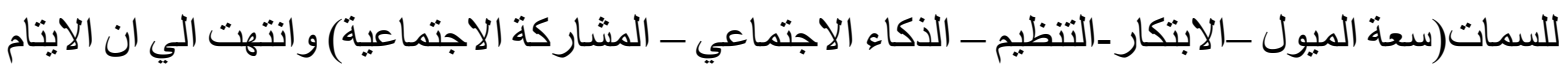

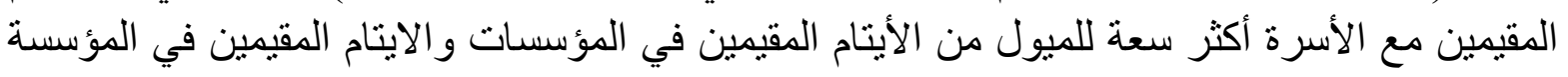
أكثر مشاركة اجتماعيا ولا يوجد فروق على سمة سمة التنظيم والابتكار و الذكاء الاجتماعي.

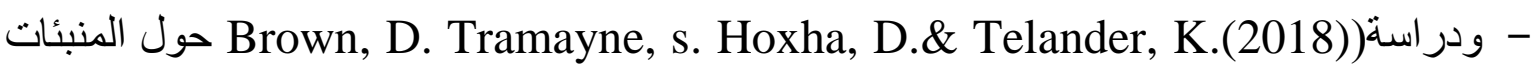
الاجتماعية و المعرفية لأداء طلاب الجامعة(الرقابة الذاتية على الوقت وجدولة العمل)، وهدفت البحث

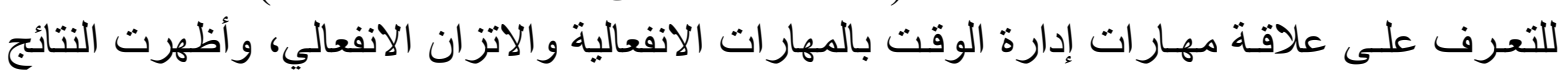

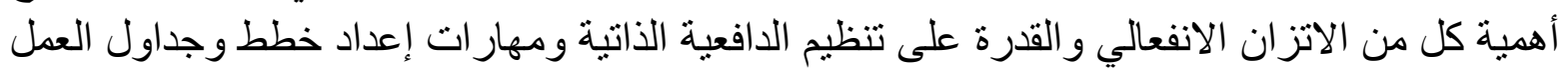

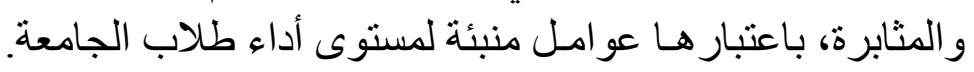

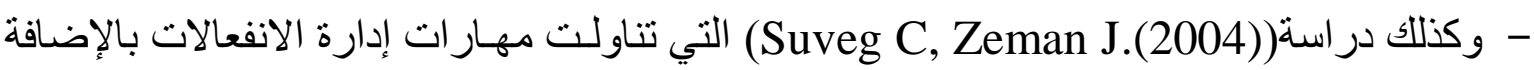

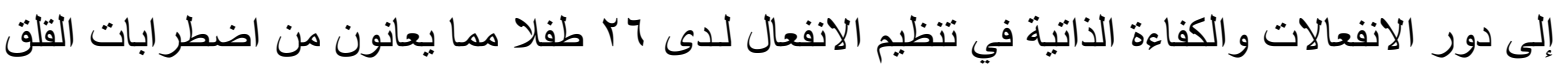

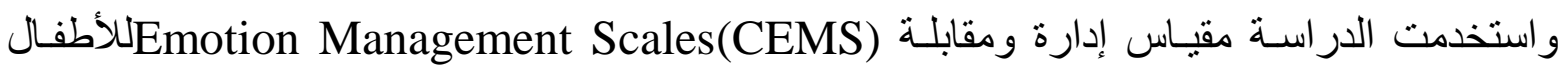

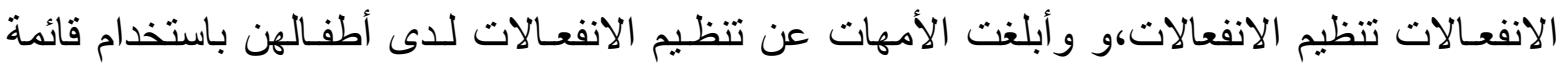

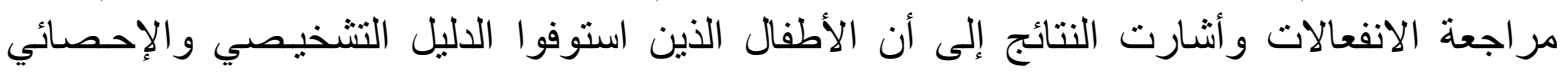

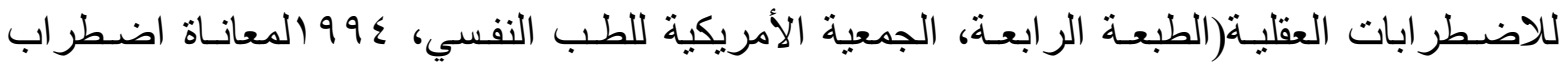




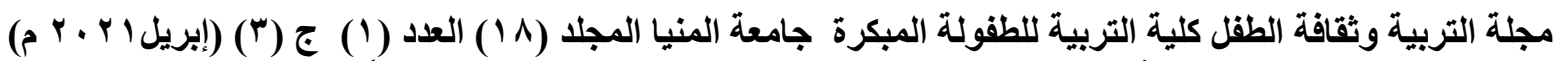

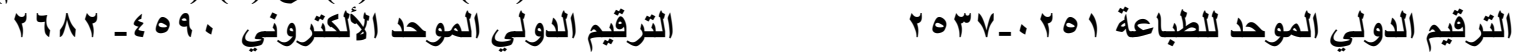

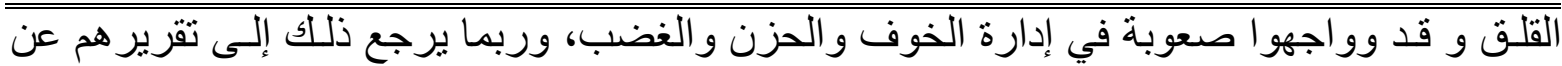

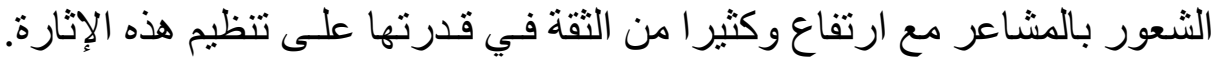

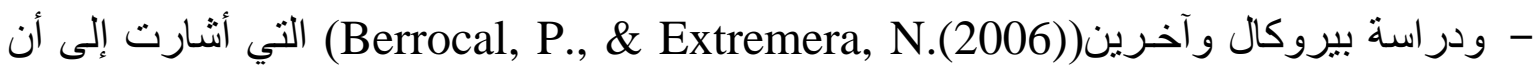

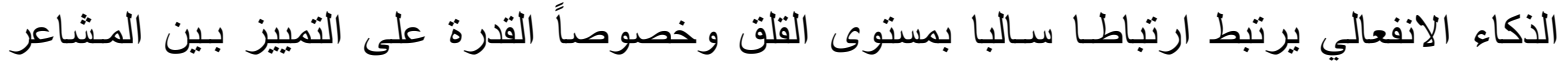

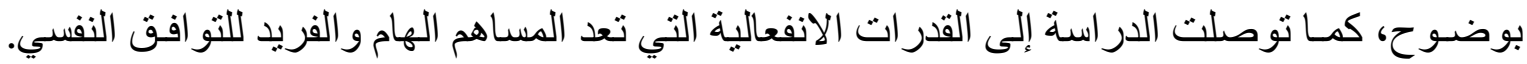
المحور الثاني:دراسات تناولت اطفال المؤسسات الإيوائية:

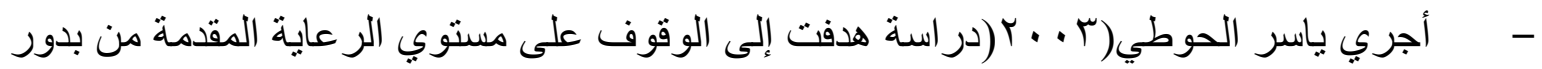

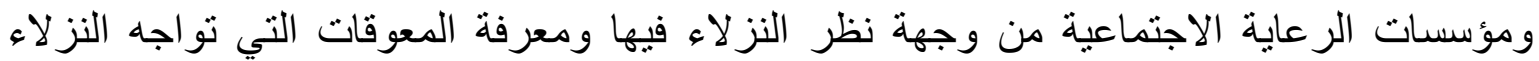

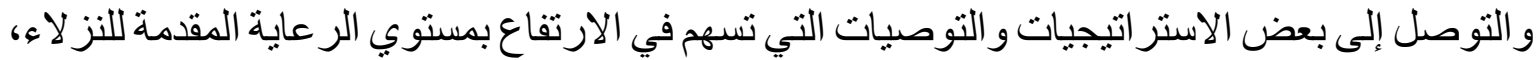

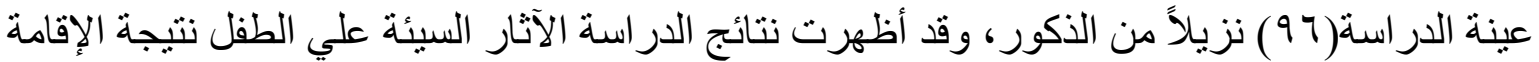

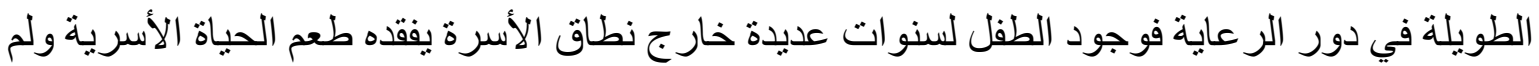

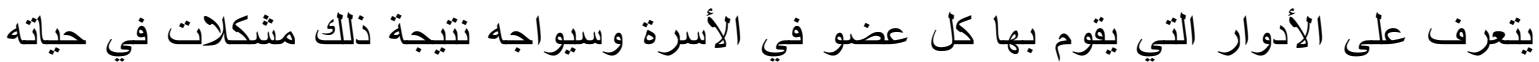

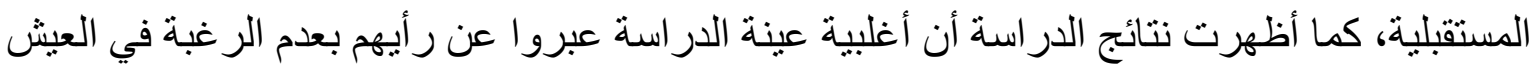
في دور الرعاية الاجتماعية، وهذا يؤكد أن الرعاية المؤسسية مهما بذل فيها من جهود لن تكون البديل المناسب للر عاية الأسرية.

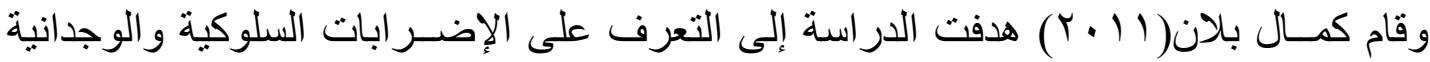

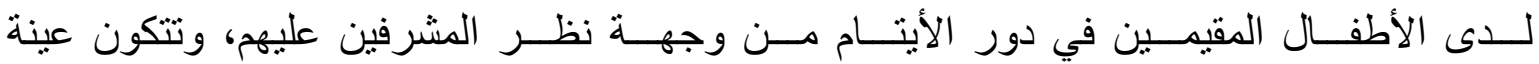

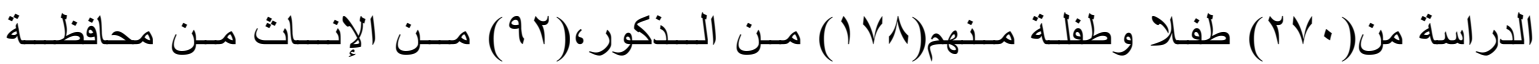

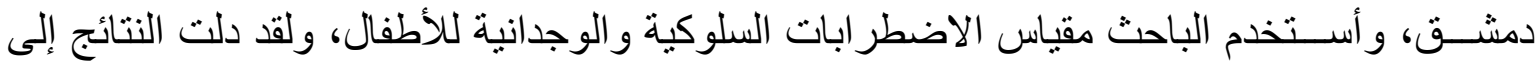

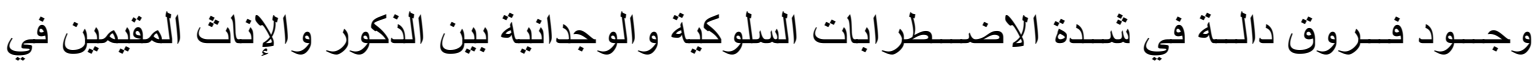
دور الأيتام. كما قامت ماجدة زقوت) ( ( ـ (ب) هدفت الدر اسة إلى التعرف على العلاقة بين هويه الذات و الثعور

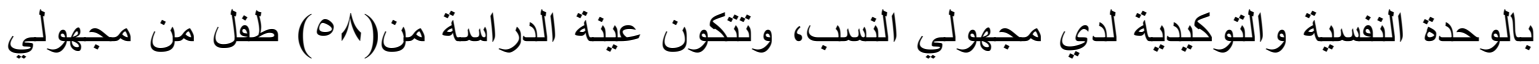

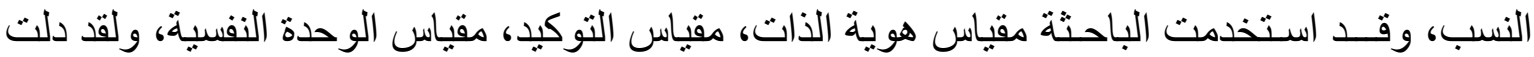

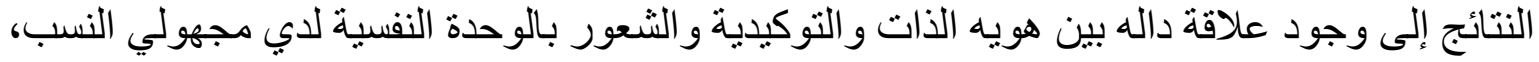
و عدم وجود فروق بين مجهولي النسب المتواجدين في الجمعية وبين المتو اجدين في الاسر البديلة.

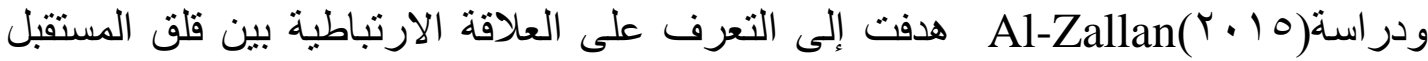

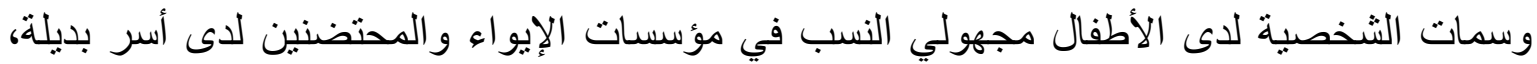

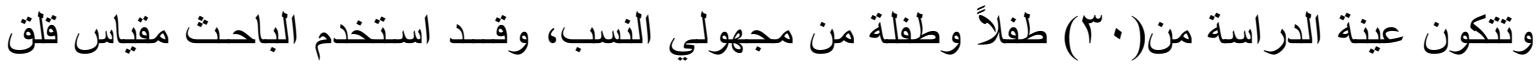

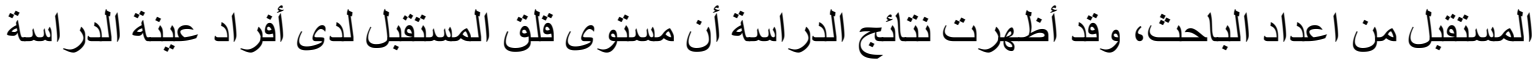




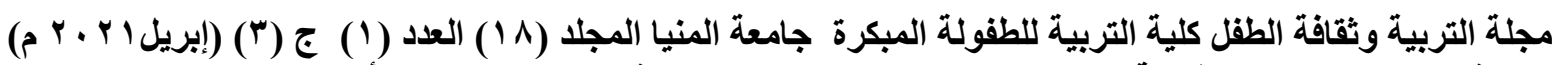

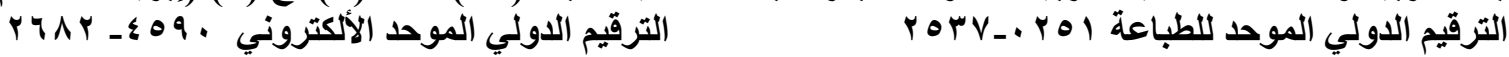

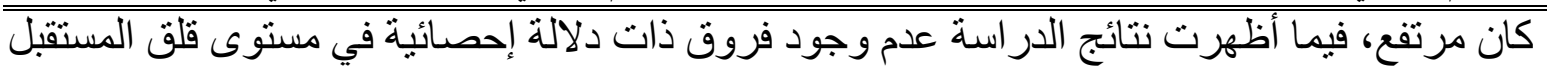
تعزى لمتغير الجنس.

\section{المحور الثالث:دراسات تثاولت الكفاعة الاجتماعية مع متغيرات أخرى:}

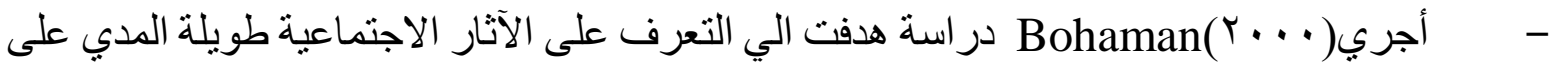

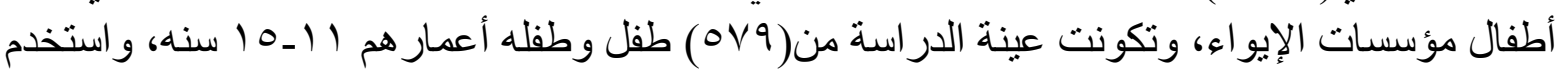

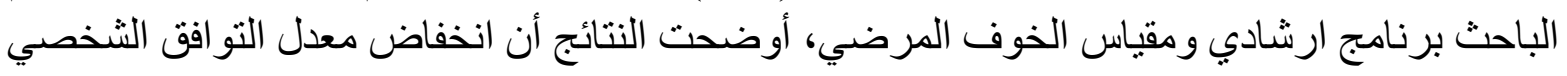

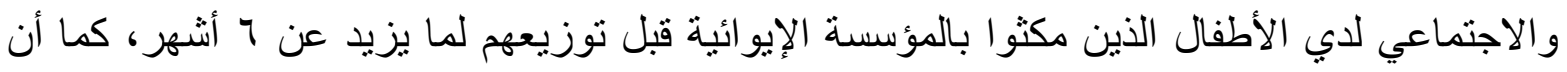

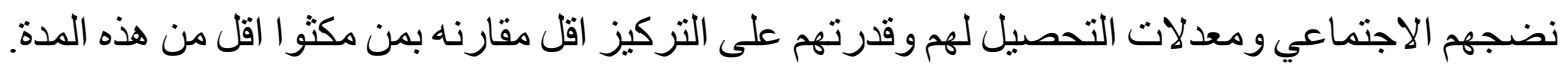

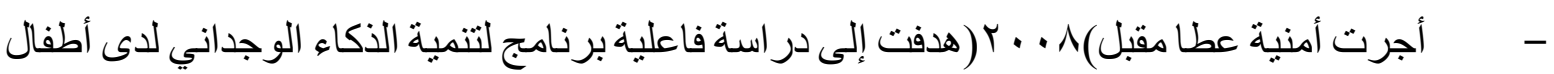

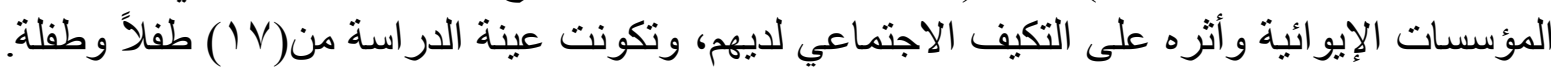

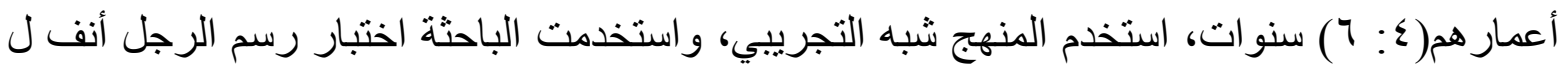

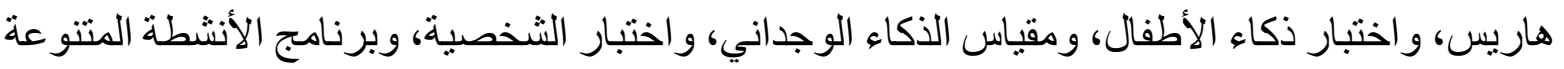

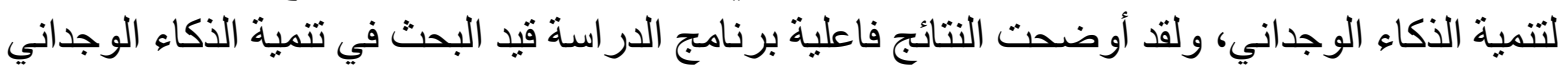

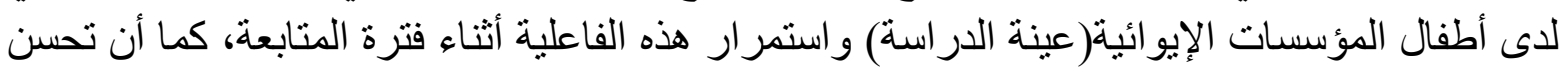

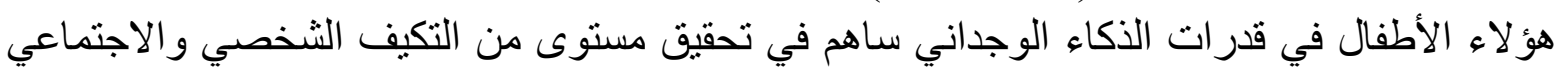

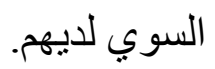

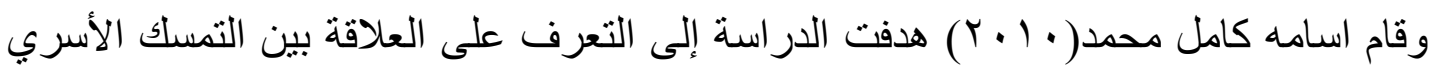

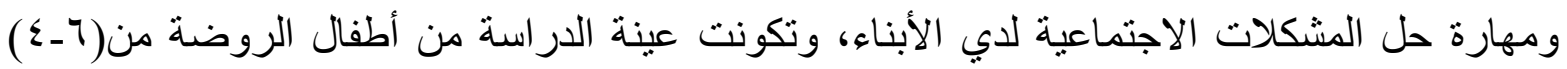

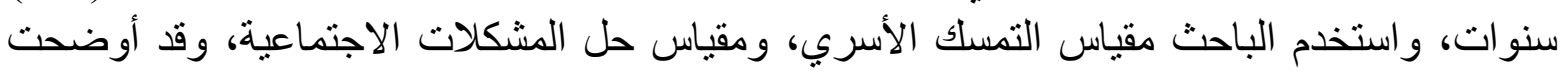

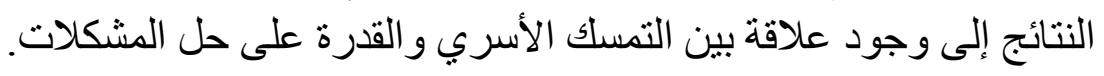

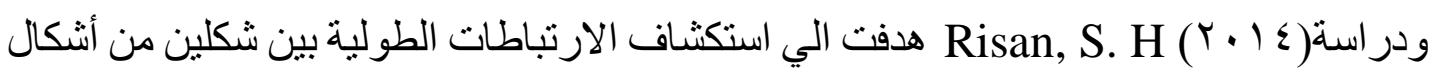

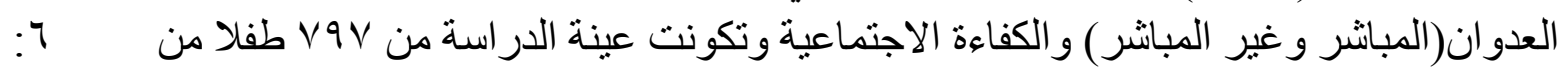

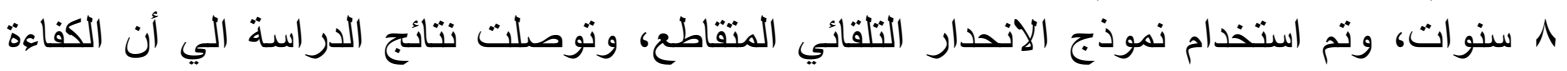

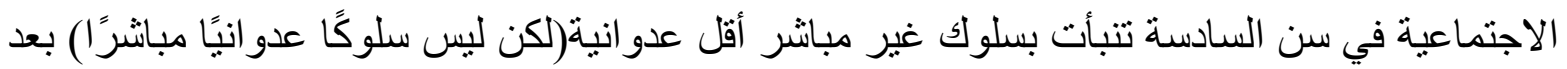

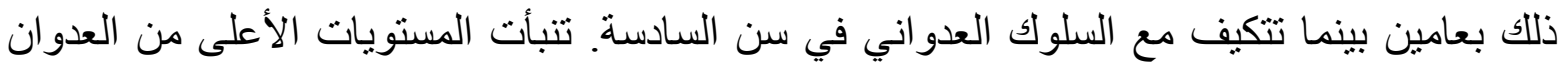

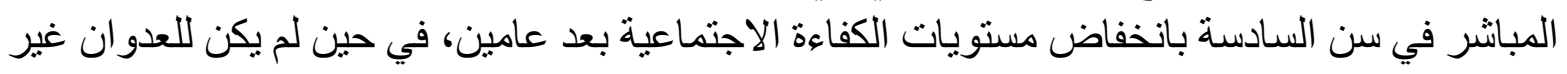

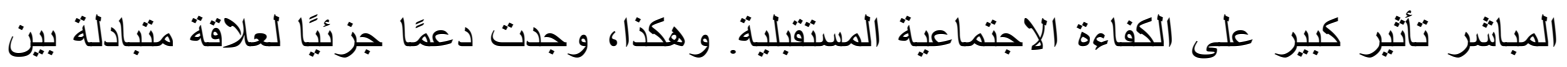

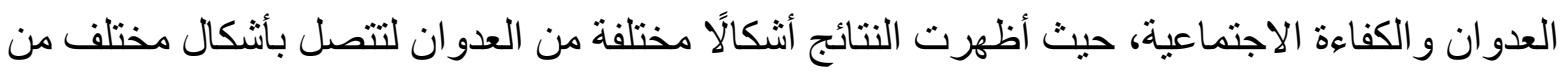

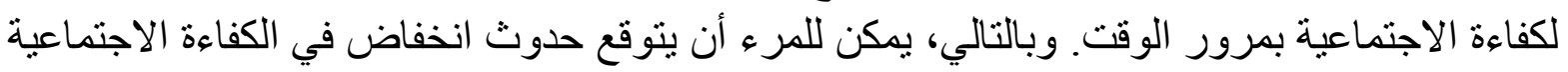
بمرور الوقت لدى الأطفال شديد العدو انية. التعقيب على الاراسات السابقة: 


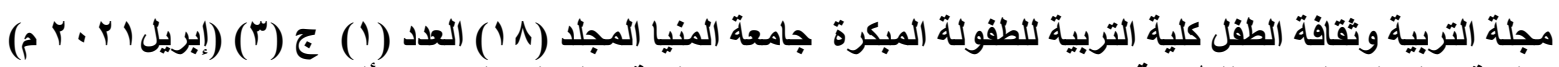

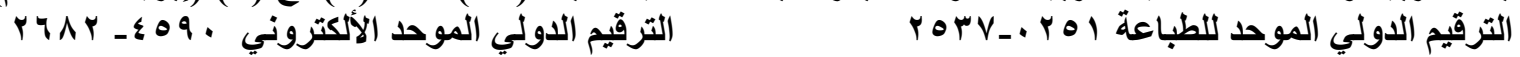
- وجود الأطفال داخل المؤسسات الإيوائية ينتج عنها بعض المشكلات النفسية والاجتماعية مثل(اضـطر ابات السلوك مثل العدوان ـ الإضر ابات الانفعالية مثل عدم الثبات الانفعالي- بالوحدة النفسيةـ انخفاض مستويات الكفاءة الاجتماعية - سوء التكيف الثخصي و الاجتماعي) - وضحت نتائج بعض الدر اسات أنه بوجد علاقة بين السمات الثخصية و الكفاءة الاجتماعية. - أوضحت نتائج بعض الدر اسات أن مفهوم الثبات الانفعالي لاى الأطفال مؤسسات الايو اء يتأثر بعو امل

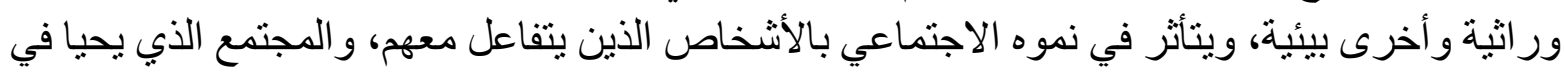
إطاره - أفادت الدر اسات السابقة الباحثة في تحديد وصياغة مشكلة البحث الر اهنة، وتحديد الإجر اءات المنهجية، ووضع فروض الدراسة، بالإضافة إلى تدعيم الإطار النظري وتفسير النتائج التي انتهت إلبهاو كذلك إعداد المقباس.

\section{فروض البحث:}

- توجد علاقة ارتباطية دالة إحصائياً بين الثبات الانفعالي و الكفاءة الاجتماعية لدي الأطفال مؤسسات الايو اءو. - توجد فروق غير دالة إحصائية بين أطفال مؤسسات الإيواء(مجهولي النسب - الأيتام - من كان و الديه محبوسين) في كلا من الثبات الانفعالي و الكفاءة الاجتماعية.

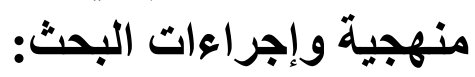

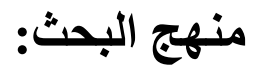

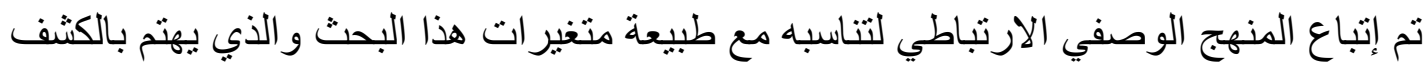
عن العلاقات القائمة بين متغيرين أو أكثر لمعرفة مدى الارتباط بين هذه المتغير ات و التعبير عنها كميا

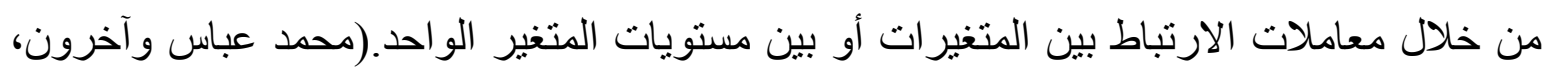
$(Y .76 V V$

\section{مجثمع البحث:}

تمثل مجتمع البحث في أطفال مؤسسات الايواء ن=( ( . ب) طفل وطفلة وتم اختيار هم بالطريقة العشو ائية من المؤسسات الإيو ائية بمحافظة المنيا ومؤسسة و احدة في محافظة القاهرة من كلا الجنسين

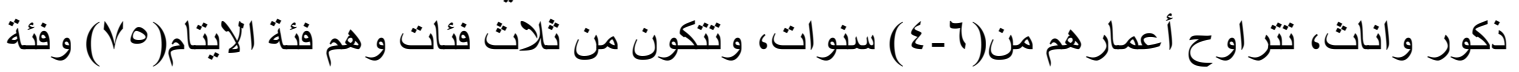

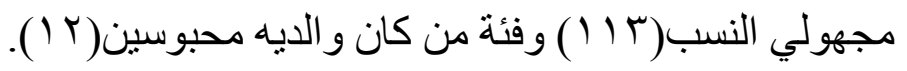

أدوات الإحث:

استخدمت الباحثة الأدوات التالية:

- مقياس السمات الثخصية المصور (إعداد الباحثة). - مقياس الكفاءة الاجتماعية(مروة مر اد حسني، ع ( ب ). 1.1 


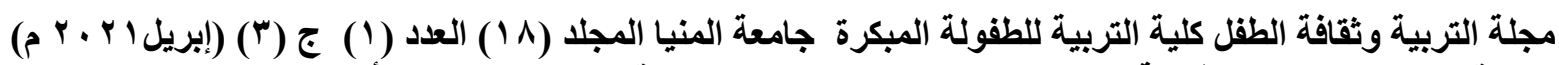

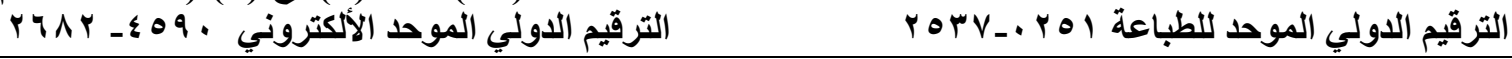

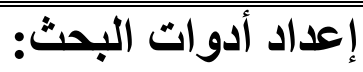

\section{ا ـ ـ مقياس السمات الشخصية المصور(إت إعداد الباحثة):}

أ.وصف المقياس:

صُمم هذا المقياس لقياس السمات الثخصية المصور لأطفال مؤسسات الإيو اء ويتكون المقياس من

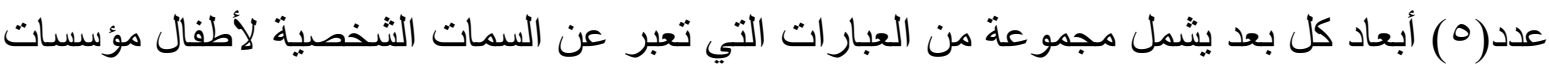

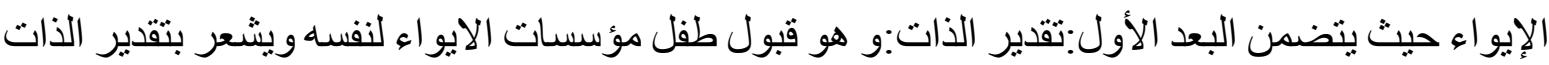

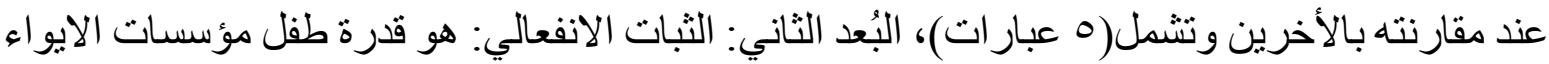

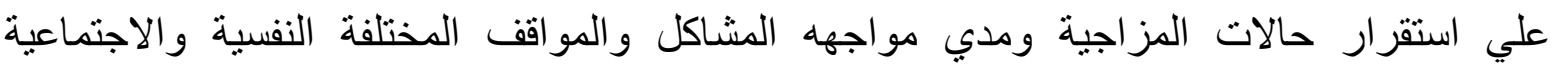

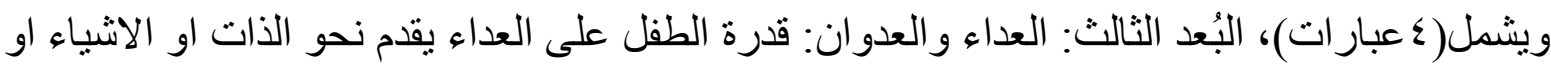

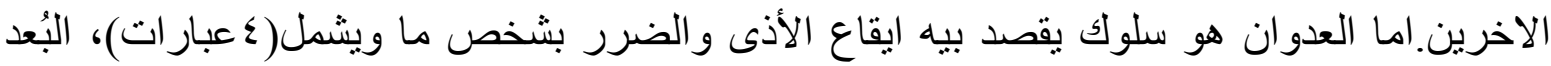

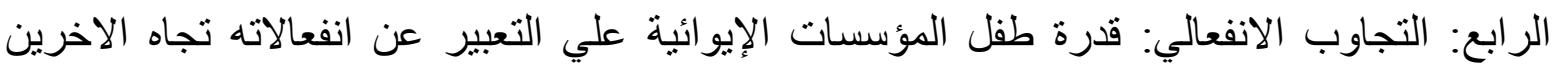

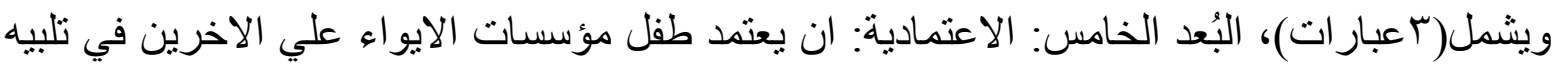

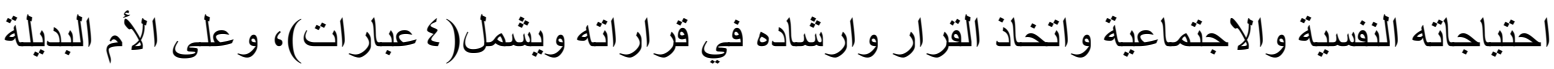
أن تختار البديل المناسب لكل عبارة حسب كل عبارة، ويطبق المقياس علي أطفال المؤسسات الإيوائية وإنية

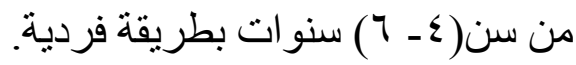
ب. بن خنوات إعداد المقياس: تم بناء هذا المقياس في ضوات أعدو المغين ما يلي:

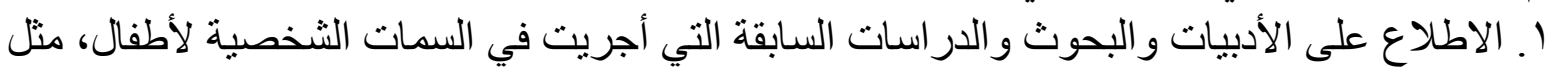

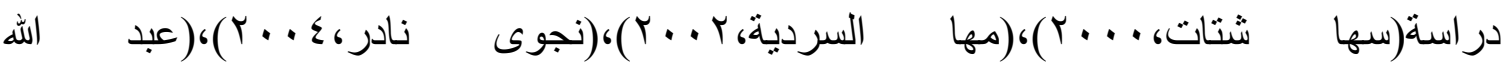

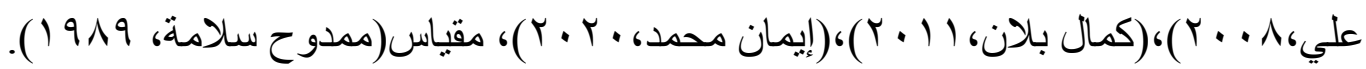

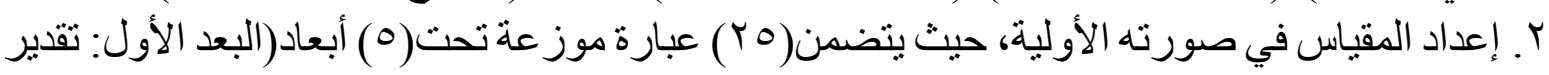

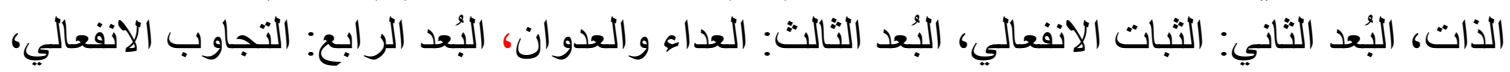
البُعد الخامس: الاعتمادية).

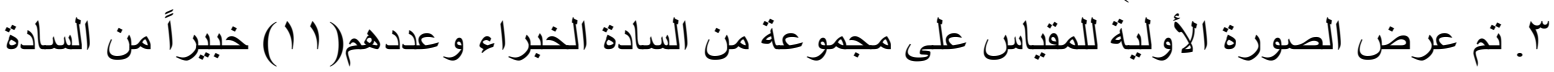

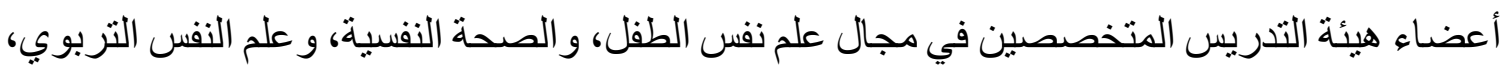
وذللك لتحديد مدى صدق المقياس.

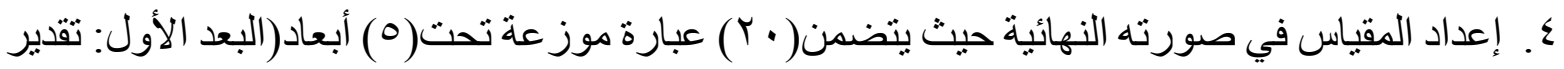

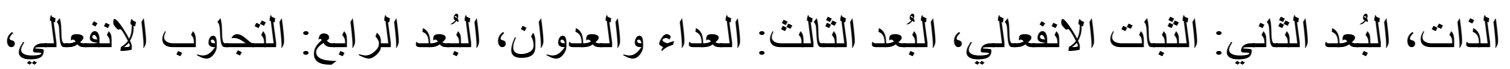
البُعد الخامس: الاعتمادية). ج. طريقة تطبيق المقياس وتصحيحه: 


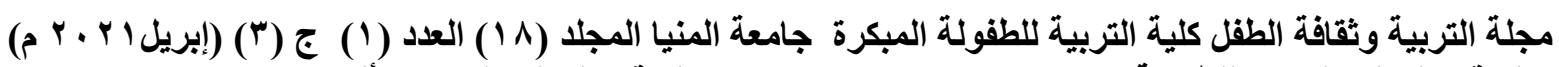

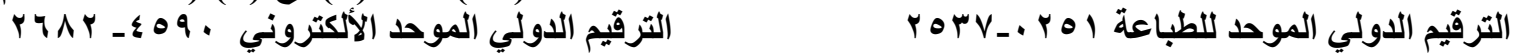

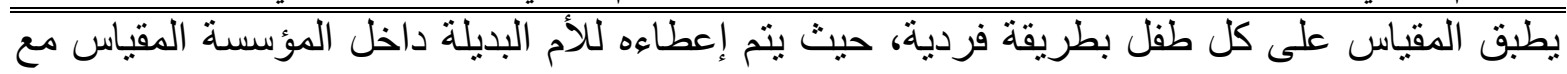
توضيح البدائل لكل عبارة وطلب منها وضع علامة(ل) تحت البديل المناسب و أمام رقم العبارة الخاص ب.

- يحصل الطفل على عدد( (1) درجة و احدة في البديل(أبدًا). - يحصل الطفل على(Y) في البديل(أحيانًا). - - يحصل الطفل على(ب) في البديل(دائمًا).

د. المعاملات العلمية للمقياس:

( ) (الصدق:

ا ـ صدق المحكمين:

قامت الباحثة بعرض المقياس في صورته المبدئية المكونة من(ب0(ب) بنداً على مجمو عة من أساتذة علم النفس و الصحة النفسية و الخبراء في مجال تربية الطفل و العلوم النفسية بلغ عددهم( (1) محكماً وذللك لإبداء الر أي في ملأئة المقياس فيما وضع من أجله سواء من حيث المحاور و العبار ات الخاصة بكل محور ومدى مناسبة تللك العبار ات للمحور الذى تمثله ومدى مناسبة الصور للعبار ات، لاته

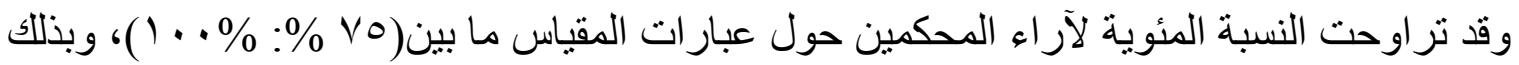

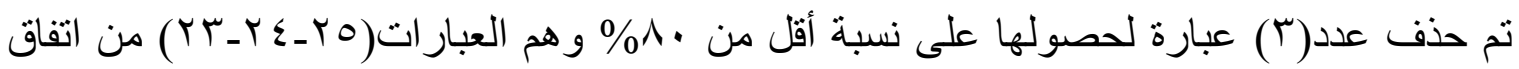
المحكمين و حذف عبارتين بعد المعاملات الإحصائية للعينة الاستطلاعية للصدق الاتساق الداخلي و هما العبارة( ب ا و ه 1) البعد الر ابع: العداء و العدوان: العبارة(0 1) البعد الخامس: التجاوب الانفعالي: العبارة(Y I)، تعديل صباغة(Y) بنود لتصبح الصورة النهائية مكونة من( • ب) عبارة. جدول(1):يوضح نسبة اتفاق المحكمين على بنود مقياس السمات الثخصية المصور

\begin{tabular}{|c|c|c|}
\hline النسبة المئوية & التكر ار & رقم البند \\
\hline$\% 90$ & 10 & 1 \\
\hline$\% 100$ & 11 & 2 \\
\hline$\% 100$ & 11 & 3 \\
\hline$\% 100$ & 11 & 4 \\
\hline$\% 990$ & 1 . & 5 \\
\hline$\% 90$ & 1. & 6 \\
\hline$\% 82$ & 9 & 7 \\
\hline$\% 82$ & 9 & 8 \\
\hline$\% 100$ & 11 & 9 \\
\hline$\%$ & 10 & 10 \\
\hline$\% 100$ & 11 & 11 \\
\hline
\end{tabular}




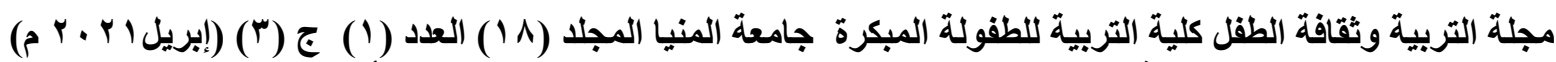

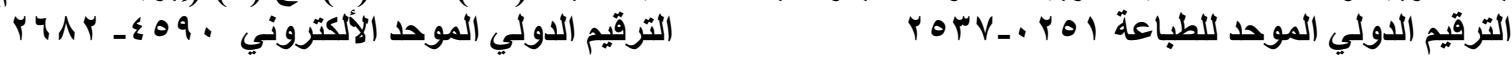

\begin{tabular}{|c|c|c|}
\hline النسبة المئوية & التكر ار & رقم البند \\
\hline$\% 72$ & 8 & 12 \\
\hline$\% 100$ & 11 & 13 \\
\hline$\% 100$ & 11 & 14 \\
\hline$\% 63$ & V & 15 \\
\hline$\% 100$ & 11 & 16 \\
\hline$\% 100$ & 11 & 17 \\
\hline$\% 90$ & 1. & 18 \\
\hline$\% 100$ & 11 & 19 \\
\hline$\% 90$ & 10 & 20 \\
\hline$\% 82$ & 9 & YI \\
\hline$\% 82$ & 9 & TY \\
\hline$\% 63$ & V & rT \\
\hline$\% 63$ & V & TE \\
\hline$\% 72$ & $\Lambda$ & ro \\
\hline
\end{tabular}

يتضح من جدول( (1) ما يلي:

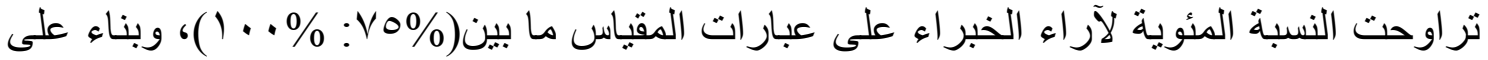

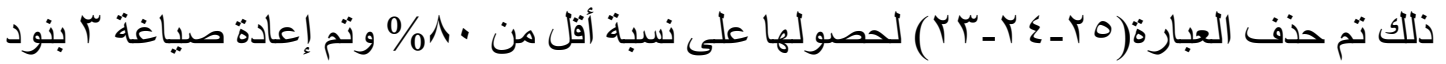

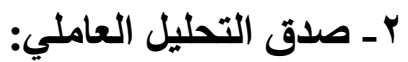

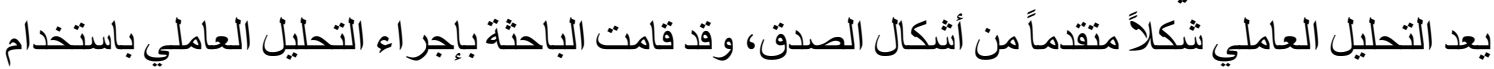
البرنامج الإحصائي SPSS، تم إجراء التحليل العاملي Factorial Analysis بطريقة المكونات الأساسية Principal Component وبعد التدوير أنتج(0) عو امل وبأخذ محك جيلفورد(r, • ) لاختيار

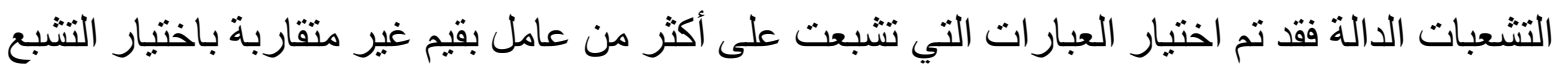

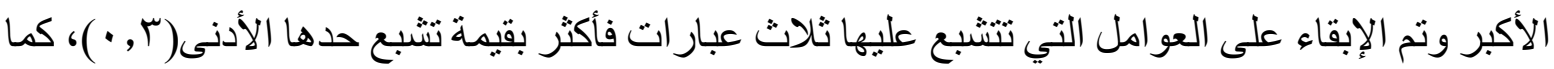

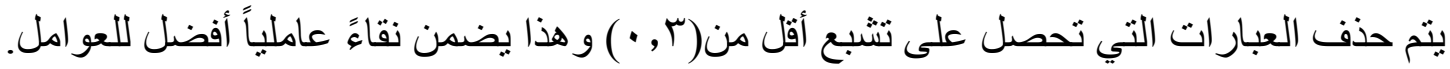
جدول(r):مصفوفة العو امل بعد التدوير

\begin{tabular}{|c|c|c|c|c|c|c|}
\hline الاشتر اكيات & الخامس & الرابع & الثالث & الثاني & الأول & رقم البند \\
\hline 0.683 & 0.074 & 0.225 & -0.088 & 0.706 & -0.347 & .1 \\
\hline 0.497 & 0.232 & 0.290 & 0.106 & -0.100 & 0.581 &.$r$ \\
\hline 0.642 & 0.360 & -0.489 & 0.239 & 0.299 & 0.355 &.$r$ \\
\hline
\end{tabular}




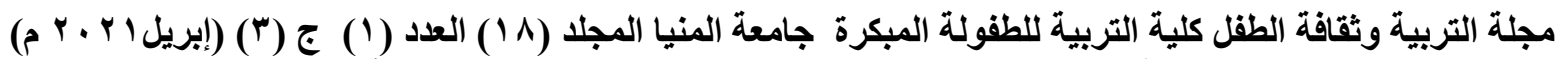

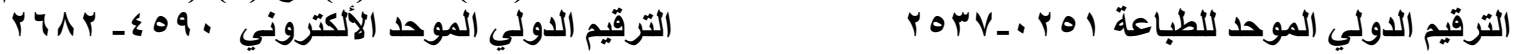

\begin{tabular}{|c|c|c|c|c|c|c|}
\hline الاشتر اكيات & الخامس & الرابع & الثالث & الثاني & الأول & رقم البند \\
\hline 0.632 & 0.069 & -0.411 & 0.483 & -0.057 & 0.470 & .8 \\
\hline 0.59 & 0.273 & 0.564 & 0.101 & -0.398 & 0.169 & .0 \\
\hline 0.752 & 0.010 & 0.239 & 0.049 & 0.783 & -0.281 & .7 \\
\hline 0.652 & 0.247 & -0.133 & -0.102 & 0.740 & -0.125 &.$V$ \\
\hline 0.508 & -0.171 & -0.099 & -0.104 & -0.353 & 0.578 &.$\wedge$ \\
\hline 0.225 & 0.394 & -0.175 & -0.165 & -0.099 & -0.049 & .9 \\
\hline 0.613 & -0.052 & 0.065 & -0.099 & -0.342 & 0.692 & .1. \\
\hline 0.623 & -0.219 & 0.085 & 0.136 & -0.155 & 0.725 & .11 \\
\hline 0.394 & -0.552 & 0.019 & 0.009 & -0.199 & 0.224 & $.1 r$ \\
\hline 0.316 & 0.398 & -0.242 & 0.119 & 0.109 & 0.269 & $.1 \%$ \\
\hline 0.462 & -0.193 & -0.148 & 0.069 & 0.094 & 0.624 & $.1 \leqslant$ \\
\hline 0.166 & 0.050 & -0.375 & -0.007 & -0.139 & 0.060 & .10 \\
\hline 0.507 & 0.693 & 0.098 & -0.124 & 0.018 & -0.024 & .17 \\
\hline 0.422 & -0.230 & 0.185 & 0.118 & 0.557 & 0.105 & $.1 \mathrm{~V}$ \\
\hline 0.567 & -0.693 & -0.088 & -0.205 & 0.057 & 0.182 & .11 \\
\hline 0.683 & 0.142 & 0.667 & 0.137 & 0.445 & -0.032 & .19 \\
\hline 0.515 & -0.104 & 0.686 & 0.041 & 0.127 & 0.123 &.$r$. \\
\hline 0.871 & -0.032 & 0.057 & 0.924 & -0.023 & 0.115 & .41 \\
\hline \multirow[t]{3}{*}{0.872} & -0.039 & 0.104 & 0.925 & 0.039 & -0.053 &.$Y Y$ \\
\hline & 2.11 & 2.19 & 2.22 & 2.81 & 2.86 & الجذور الكامنة \\
\hline & 9.61 & 9.96 & 10.09 & 12.75 & 13.01 & نسبة التباين \\
\hline
\end{tabular}

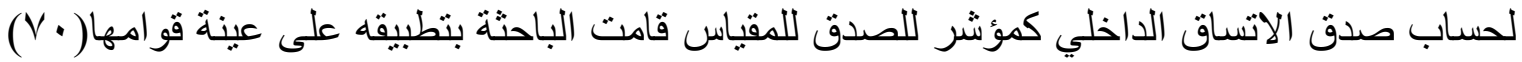

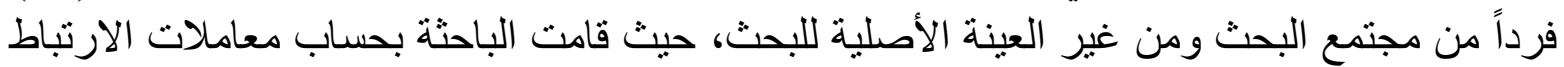

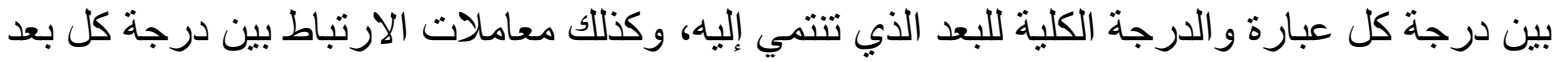

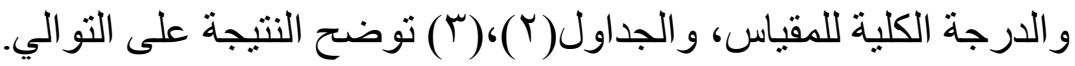




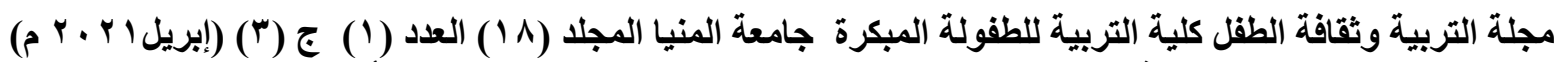

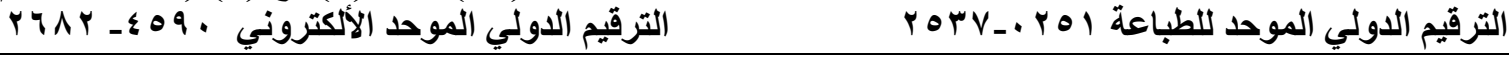

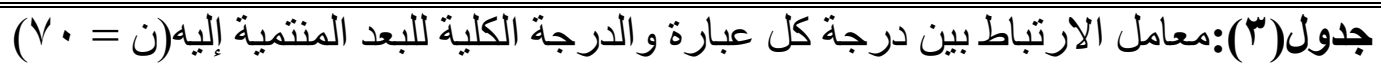

\begin{tabular}{|c|c|c|c|c|c|c|}
\hline & & & & & العبار ات & الأبعاد \\
\hline 14 & 11 & 10 & 8 & 2 & رقم العبارة & \multirow{2}{*}{ تقدير الذات } \\
\hline$* * 0.61$ & $* * 0.76$ & $* * 0.81$ & $* * 0.71$ & $* * 0.58$ & معامل الارتباط & \\
\hline & 17 & 7 & 6 & 1 & رقم العبارة & \multirow{2}{*}{ الاعتمادية } \\
\hline & $* * 0.67$ & $* * 0.69$ & $* * 0.88$ & $* * 0.77$ & معامل الارتباط & \\
\hline & & 22 & 21 & 4 & رقم العبارة & \multirow{2}{*}{ الثبات الانفعالي } \\
\hline & & $* * 0.87$ & $* * 0.91$ & $* * 0.70$ & معامل الارتباط & \\
\hline 20 & 19 & 15 & 5 & 3 & رقم العبارة & \multirow{2}{*}{ العداء و العدوان } \\
\hline$* * 0.61$ & $* * 0.58$ & 0.21 & $* * 0.42$ & $* * 0.35$ & معامل الارتباط & \\
\hline 18 & 16 & 13 & 12 & 9 & رقم العبارة & \multirow{2}{*}{ التجاوب الانفعالي } \\
\hline$* 0.28$ & $* * 0.48$ & $* * 0.39$ & 0.16 & $* * 0.74$ & معامل الارتباط & \\
\hline
\end{tabular}

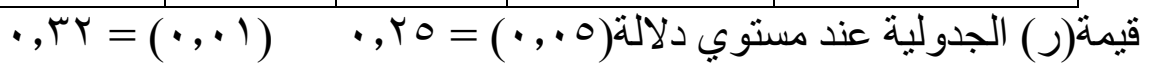

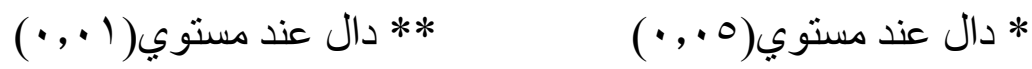

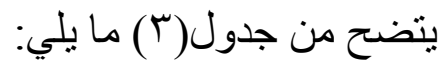

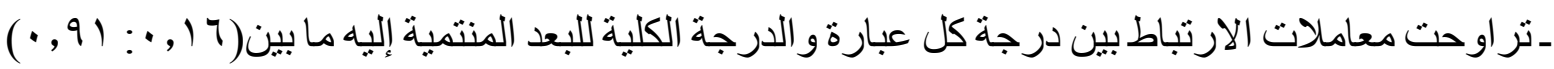

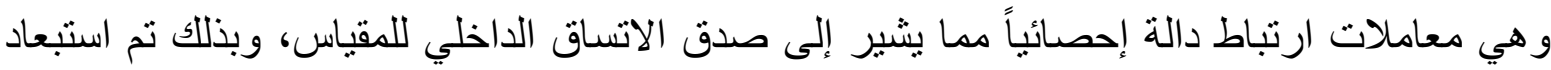

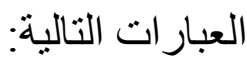

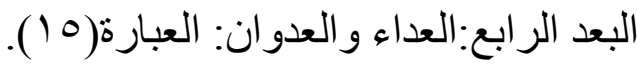

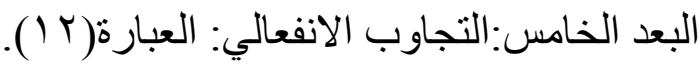

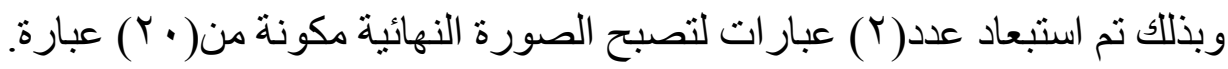

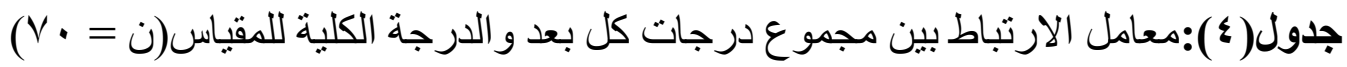

\begin{tabular}{|c|c|c|}
\hline معامل الارتباط & الأبعاد & م \\
\hline$* * 0.59$ & تقدير الذات & 1 \\
\hline$* 0.26$ & الاعتمادية & T \\
\hline$* * 0.43$ & الثبات الانفعالي & $r$ \\
\hline$* * 0.53$ & العداء و العدوان & $\varepsilon$ \\
\hline$* * 0.33$ & التجاوب الانفعالي & 0 \\
\hline
\end{tabular}

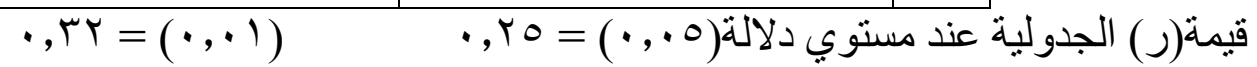

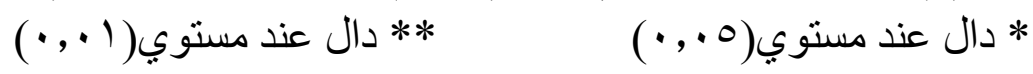

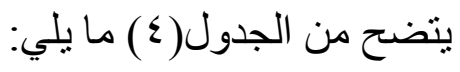




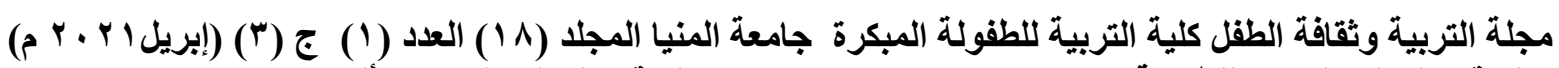

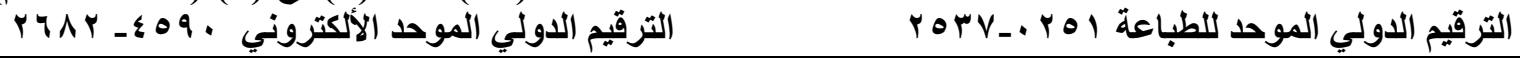

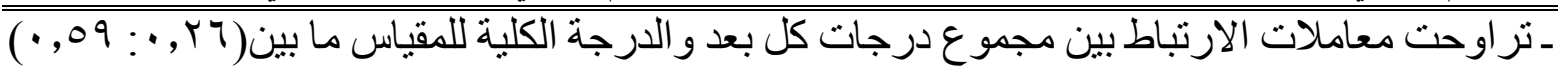

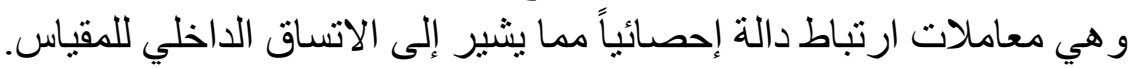

لحساب ثبات المقياس قامت الباحثة باستخدام معامل ألفا لكرونباخ وذللك بتطبيقها على عينة

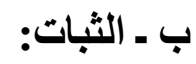

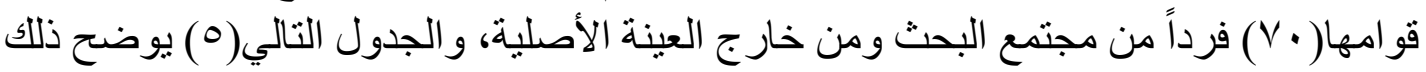

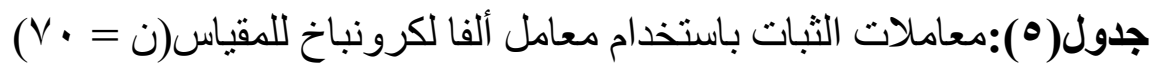

\begin{tabular}{|c|c|}
\hline معامل الفا & الأبعاد \\
\hline$* * 0.78$ & تقدير الذات \\
\hline$* * 0.80$ & الاعتمادية \\
\hline$* * 0.84$ & الثبات الانفعالي \\
\hline$* * 0.58$ & العداء و العدوان \\
\hline$* * 0.59$ & التجاوب الانفعالي \\
\hline$* * 0.75$ & الدرجة الكلية \\
\hline
\end{tabular}

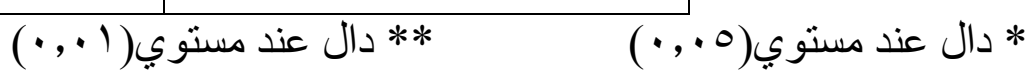
يتضح من جدول(0) ما يلي:

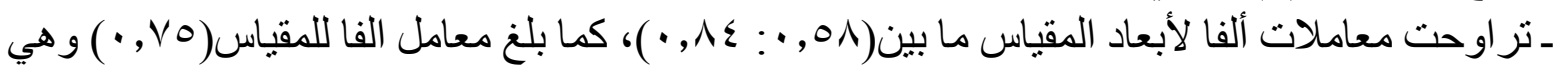

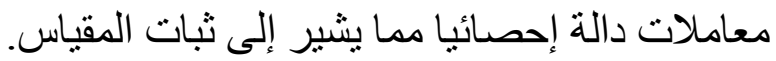

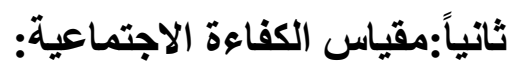
وصف المقياس:

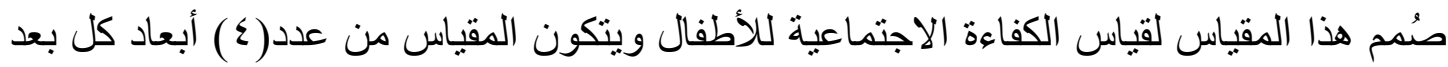

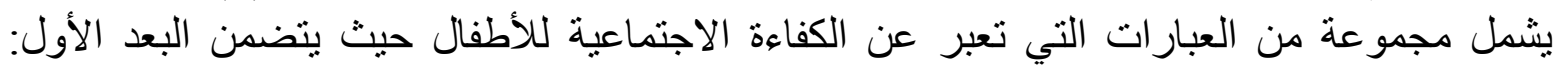

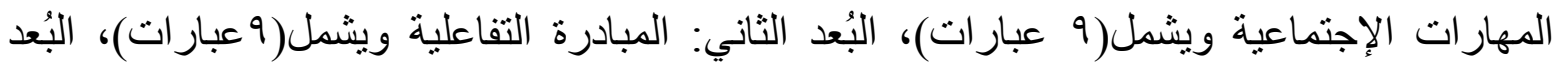

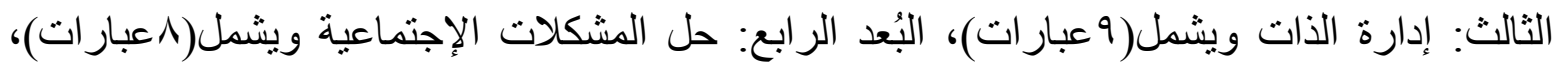

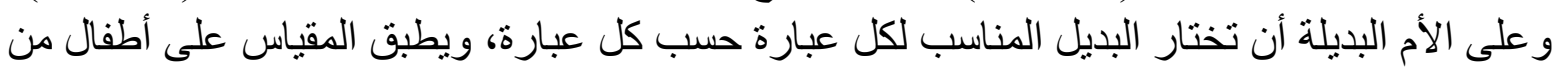
سن(ع - 1 ) سنو ات بطريقة فردية. طريقة تطبيق المقياس وتصحيحه:

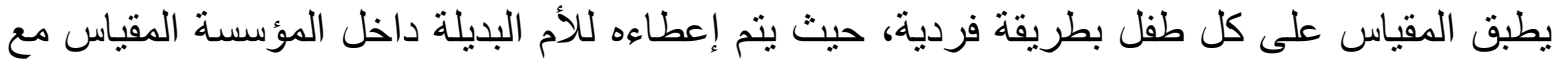

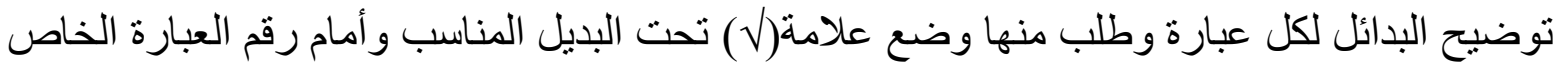
بها.

- - يحصل الطفل على عدد( (1) درجة و احدة في البديل(أبدًا). - - يحصل الطفل على(Y) في البديل(أحيانًا). 


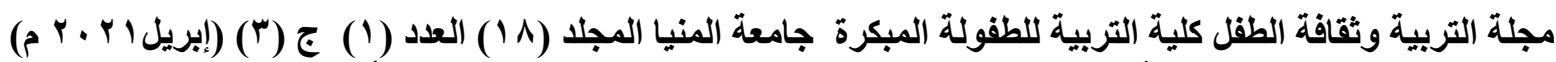

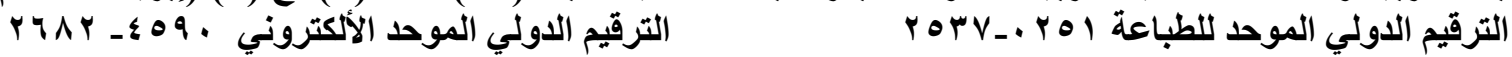

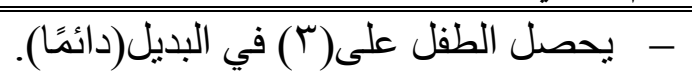
المعاملات العلمية للمقياس:

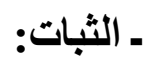

لحساب ثبات المقياس قامت الباحثة باستخدام معامل ألفا لكرونباخ وذلك بتطبيقها على عينة قو امها( • (T)

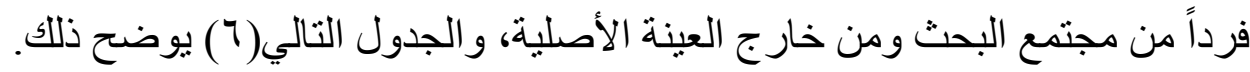

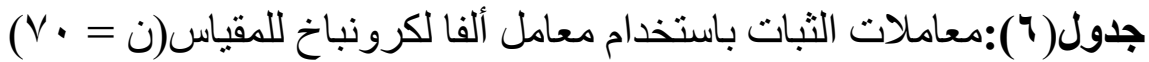

\begin{tabular}{|c|c|}
\hline معامل الفا & الأبعاد \\
\hline$* * 0.77$ & المهار ات الاجتماعية \\
\hline$* * 0.76$ & المبادرة التفاعلية \\
\hline$* * 0.72$ & إدارة الذات \\
\hline$* * 0.78$ & حل المشكلات الاجتماعية \\
\hline$* * 0.86$ & الدرجة • الكلية \\
\hline
\end{tabular}

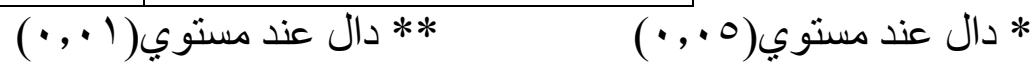

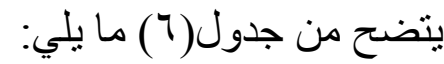

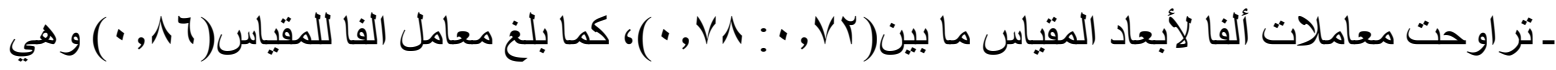

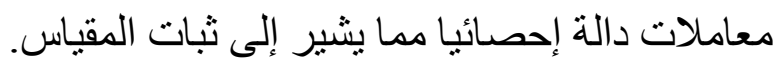
الأساليب الإحصائية: استخدمت الباحثة الأساليب الإحصائية التالية:

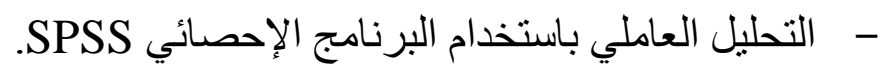

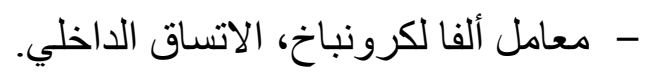
- الانحر اف المعياري و المتوسط الحسابي، استخدام اختبار كاب.

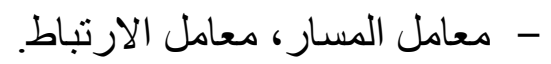
- تحليل التباين أحادي الاتجاه، تحليل الانحدار التدريجي. عرض التتائج ومناقشتها: الفرض الأول: توجد علاقة ارتباطية دالة إحصائياً بين سمات الثخصية و الكفاءة الاجتماعية لدي الأطفال

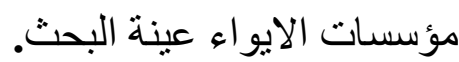

جدول(V):معاملات الارتباط بين الثبات الانفعالي و الكفاءة الاجتماعية لدي الأطفال عينة البحث

$$
\begin{gathered}
(r . .= \\
1 . \wedge
\end{gathered}
$$




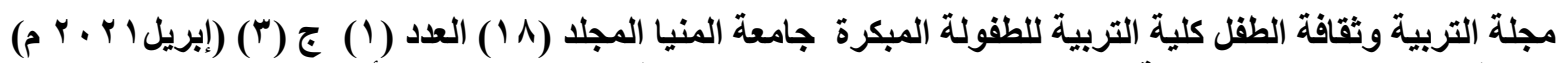

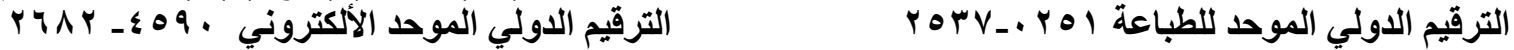

\begin{tabular}{|c|c|c|c|c|c|c|}
\hline \multicolumn{5}{|c|}{ الكفاءة الاجتماعية } & \multirow{2}{*}{\multicolumn{2}{|c|}{ المتغير ات }} \\
\hline الدرجية & الالمشكلات & إدارة الذات & التفاعلية & الاجتماعية المهار & & \\
\hline$* * 0.32$ & $* * 0.32$ & $* * 0.35$ & $* * 0.36$ & $* * 0.36$ & 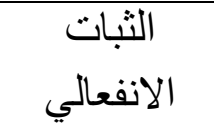 & سمات \\
\hline$* * 0.47$ & $* * 0.48$ & $* * 0.42$ & $* * 0.43$ & $* * 0.33$ & الدرجة الكلية & \\
\hline
\end{tabular}

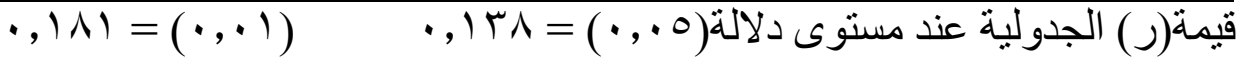

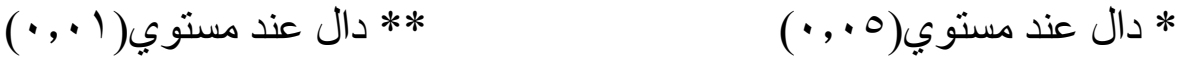

$$
\begin{aligned}
& \text { يتضح من جدول(V) ما يلي: }
\end{aligned}
$$

- - توجد علاقة ارتباطيه طردية دالة إحصائياً بين الثبات الانفعالي وكل من المهار ات الاجتماعية،

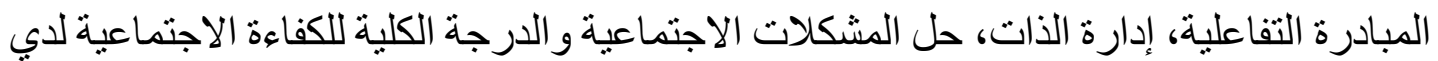

\section{أطفال مؤسسات الايو اء عينة البحث}

\section{تفسير نتائج الفرض الأول:}

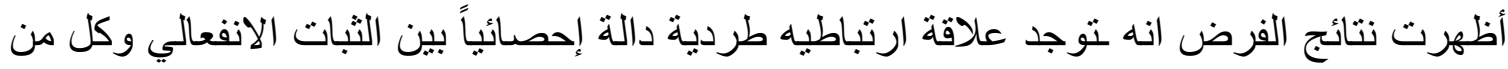

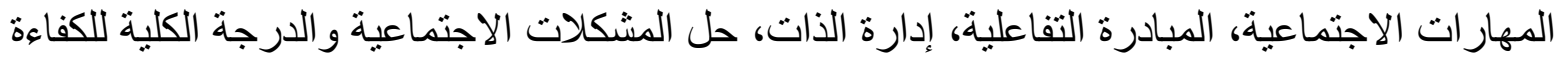

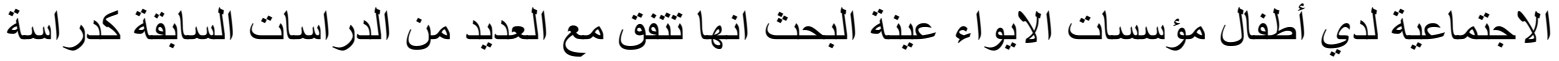

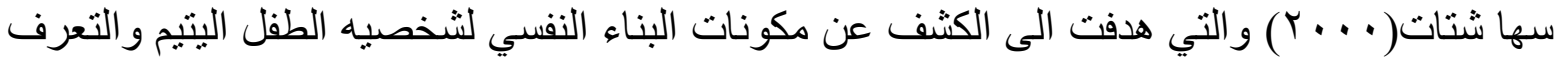

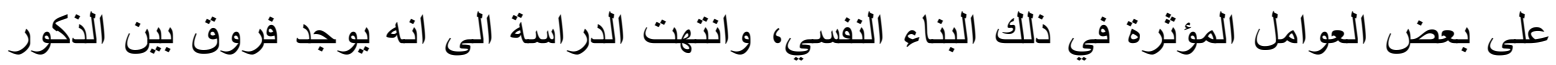

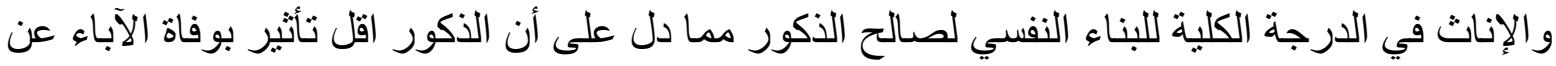

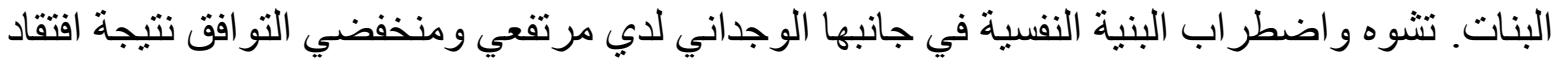

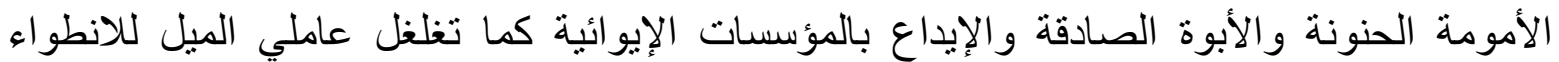
و الاستعداد للاضطر اب النفسي في جميع أفر اد العينة.

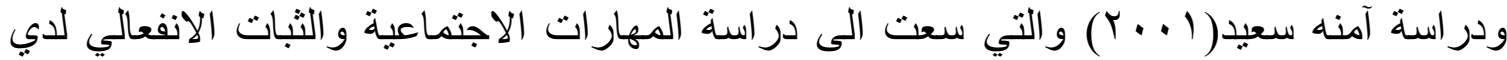

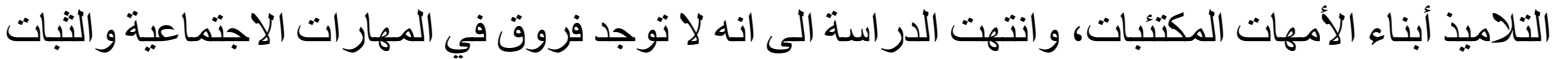

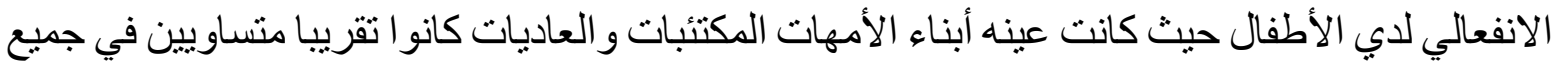

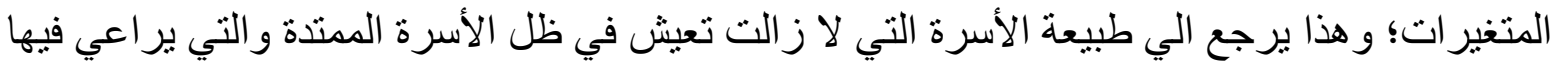
الاطفال بطريقه جيده.

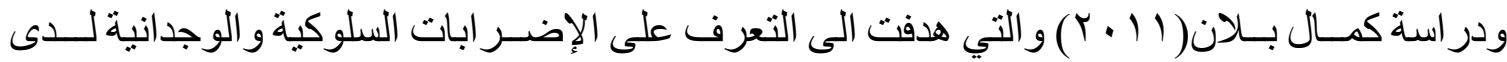

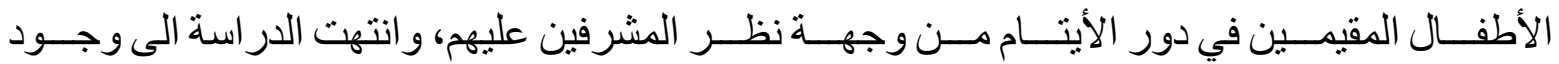
فــروق دالــة في شــدة الاضــــر ابات السلوكية والوجدانية بين الذكور و الإناث المقيمين في دور الأيتام. 


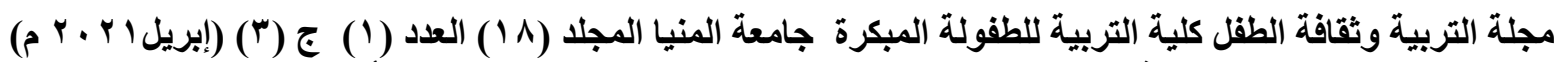

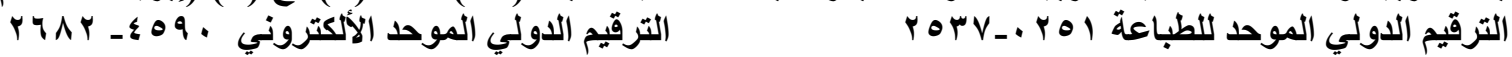

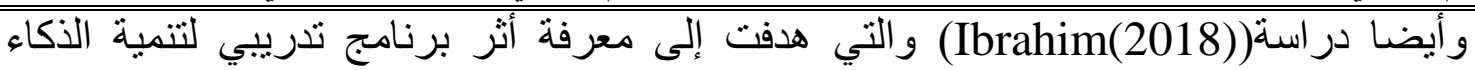

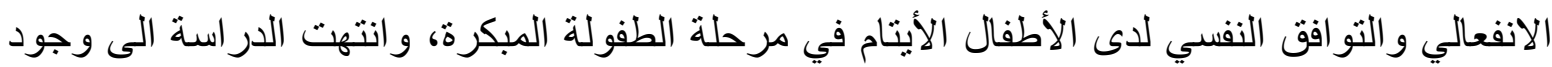

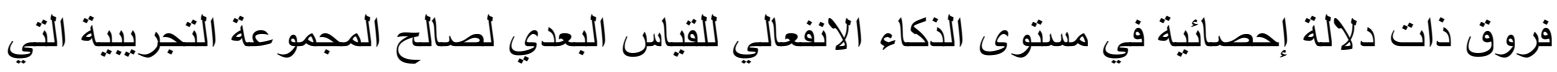
خضعت للبرنامج التدريبي. وتعزو الباحثة نتائج الفرض الى ان اختلاف الثبات الانفعالي لدى الأطفال بصفة عامة يرجع الى ان

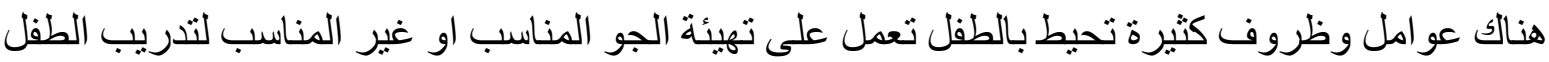

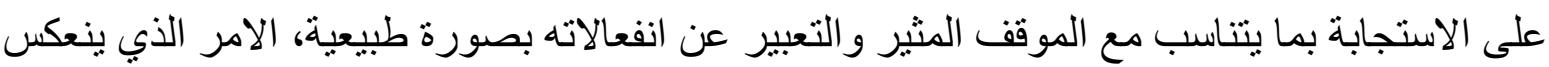

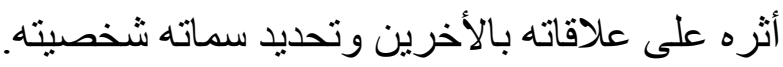

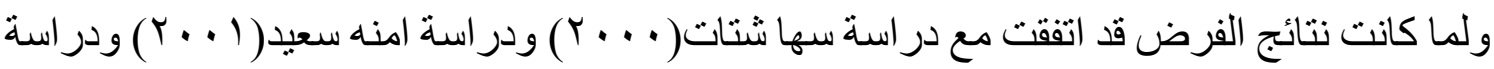

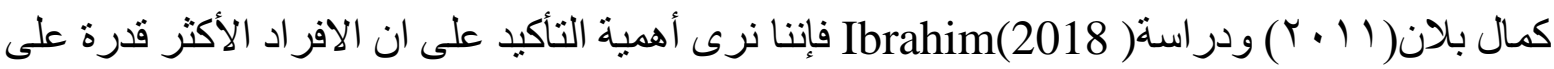

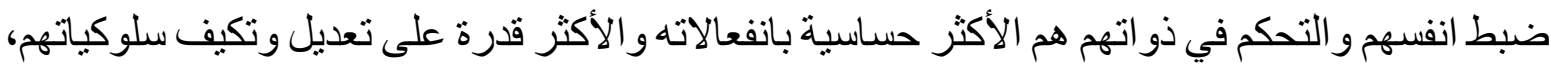

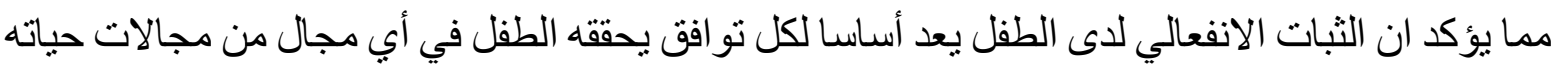

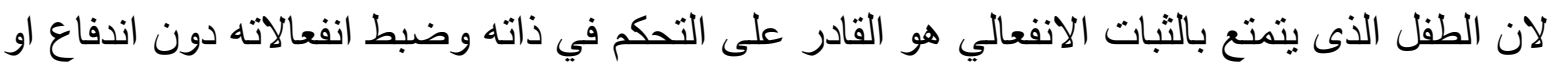

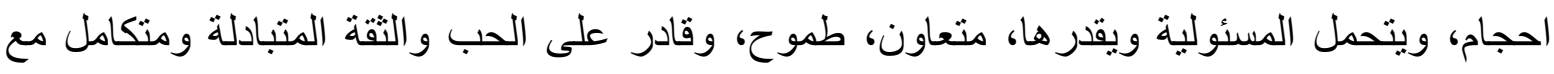

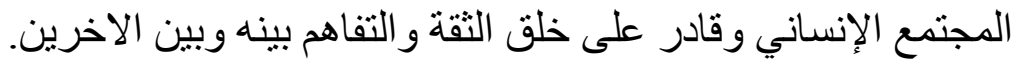

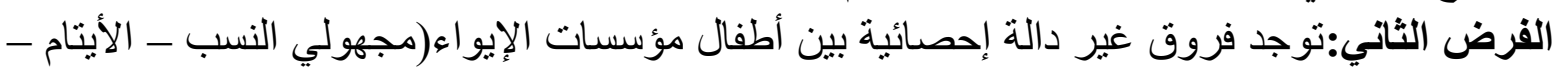

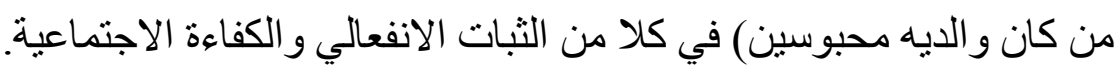

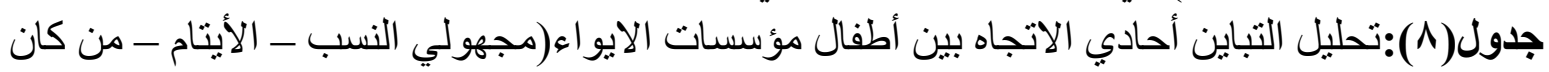

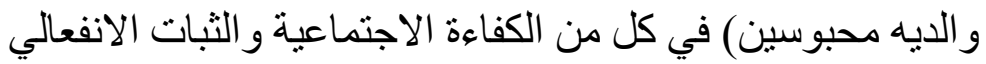

\begin{tabular}{|c|c|c|c|c|c|c|}
\hline فيمة & متوسط & الحرجة & مجموع المر بعات & مصدر التبيان & \multicolumn{2}{|c|}{ المتغير ات } \\
\hline \multirow{2}{*}{$1,1 \leq$} & 3.22 & 2.00 & 6.45 & بين المجمو عات & \multirow{2}{*}{ الانفعالي } & \\
\hline & 2.84 & 197.00 & 558.55 & داخل المجمو عات & & \\
\hline \multirow{2}{*}{$1, \Gamma \varepsilon$} & 21.39 & 2.00 & 42.79 & بين المجمو عات & \multirow{2}{*}{ الاجهار اتماعية } & \multirow{8}{*}{ الاجتماعية } \\
\hline & 16.03 & 197.00 & 3157.43 & داخل المجمو عات & & \\
\hline \multirow{2}{*}{ זד, } & 9.30 & 2.00 & 18.60 & بين المجمو عات & \multirow{2}{*}{ التفاعلية } & \\
\hline & 14.78 & 197.00 & 2911.40 & داخل المجمو عات & & \\
\hline \multirow{2}{*}{$\cdot, Y Y$} & 2.51 & 2.00 & 5.02 & بين المجمو عات & \multirow{2}{*}{ إدارة الذات } & \\
\hline & 11.41 & 197.00 & 2247.60 & داخل المجمو عات & & \\
\hline \multirow{2}{*}{$\cdot, 9 V$} & 21.63 & 2.00 & 43.27 & بين المجمو عات & \multirow{2}{*}{ حل المشكلات } & \\
\hline & 22.30 & 197.00 & 4392.74 & داخل المجمو عات & & \\
\hline
\end{tabular}




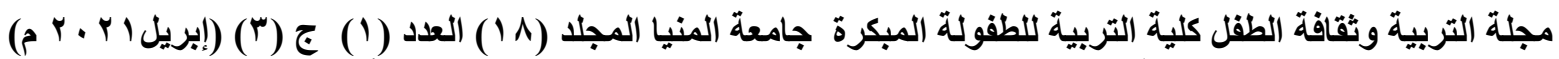

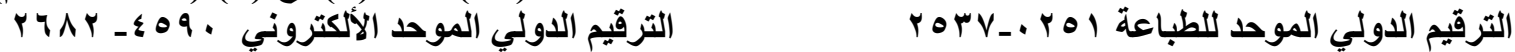

\begin{tabular}{|c|c|c|c|c|c|}
\hline فيمة & متوسط & الحرية & المربعات & مصدر التبيان & لمتغير ات \\
\hline \multirow{2}{*}{$\cdot, 94$} & 74.88 & 2.00 & 149.75 & بين المجموعات & \multirow{2}{*}{ الدرجة الكلية } \\
\hline & 80.34 & 197.00 & 15826.12 & داخل المجمو عات & \\
\hline
\end{tabular}

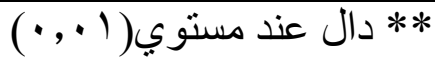

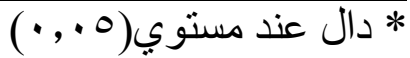
يتضح من جدول(^) ما يلي: ـ توجد فروق غير دالة إحصائياً بين أطفال مؤسسات الإيو اء(مجهولي النسب ـ الأيتام - من كان و الديه

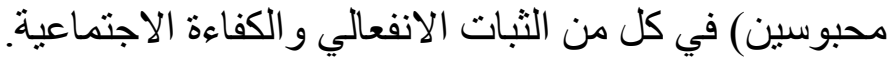
تبين من خلال الجدول السابق ما يلي:

- لوحظ عدم وجود فروق جوهرية ذات دلالة إحصائية عند مستوي(0. +. •) في درجات الثبات

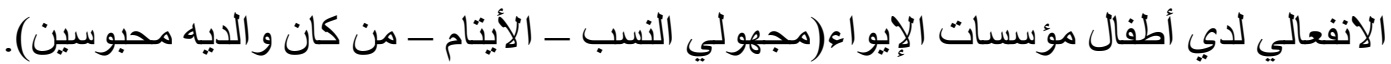
تفسير ومناقشة نتائج الفرض الثفال مؤنات الثاني:

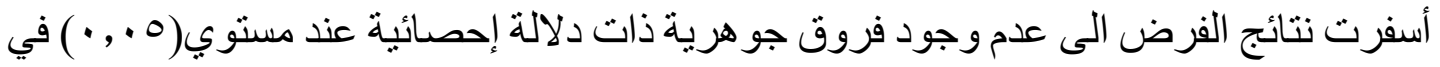

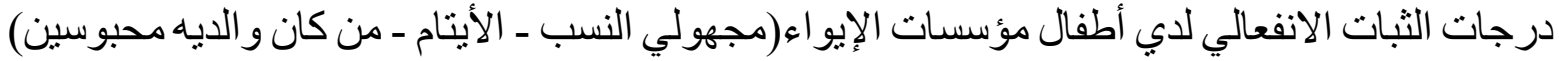

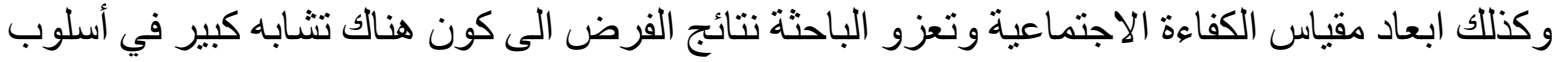

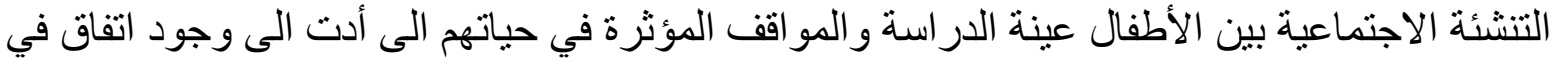

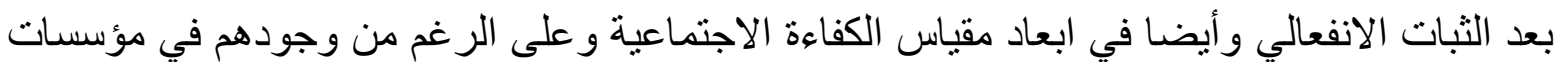

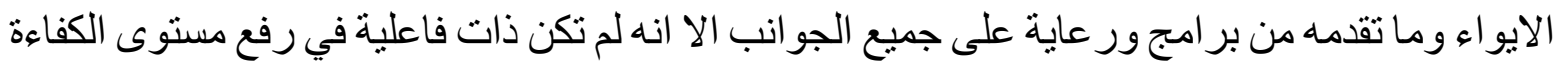

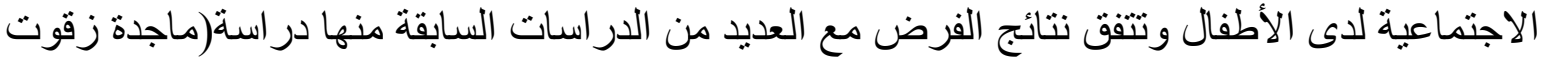

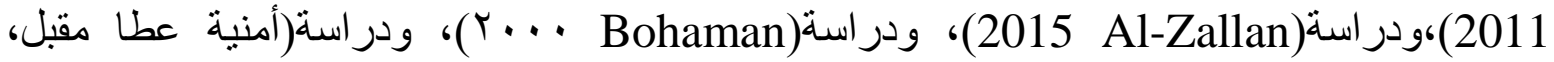

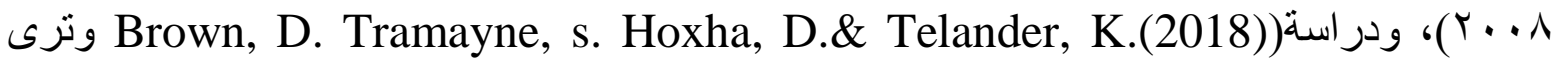
الباحثة وفقا للنتائج ضرورة العمل على تطبيق بر امج متخصصة لرفع سمات الثخصية لدى الأطفال ومن وتري ثم رفع كفاءتهم الاجتماعية.

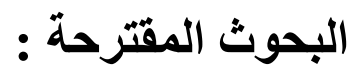

إن إجر اء الباحثة لدر اسة مشكلة معينة لا بعني إطلاقاً أنها أحاطت بجميع جو انبها و أكثر إفادة مها

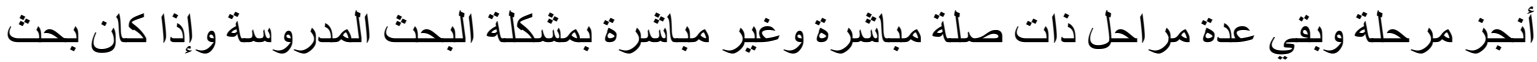

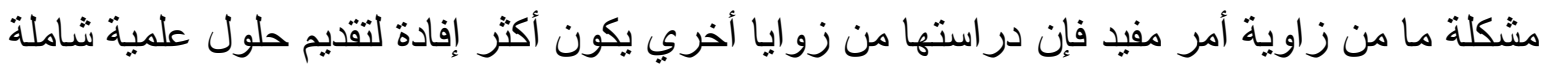

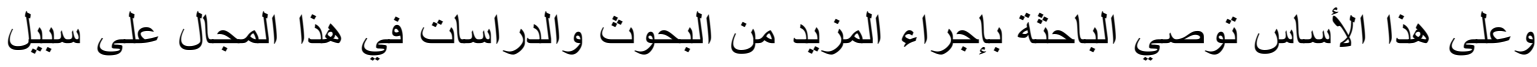
الإقتر اح:

هر اسة أنماط الشخصية المميزة لكل من الأيتام ومجهولي النسب. • الكثف عن الديناميات النفسية المصاحبة لمجهولي النسب و الأيتام من خلال نظرية التحليل النفسي. 


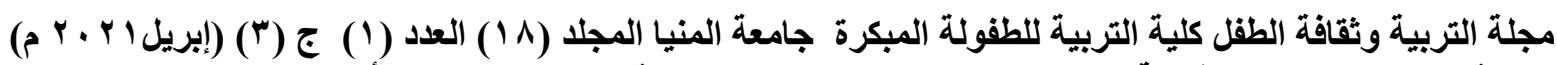

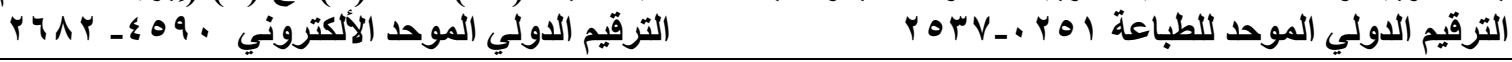

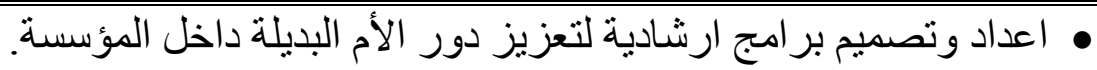

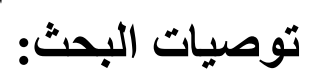
تعتبر القيمة الحقيقية لأي در اسة علمية هي قدرتها علي فتح آفاق و أفكار جديدة، وأن تشير نتائجها للمزيد

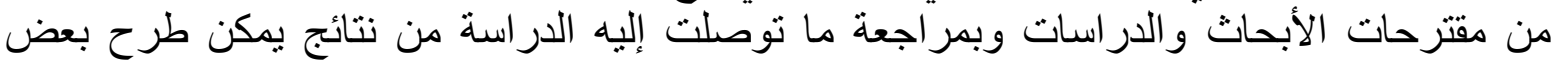

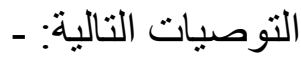

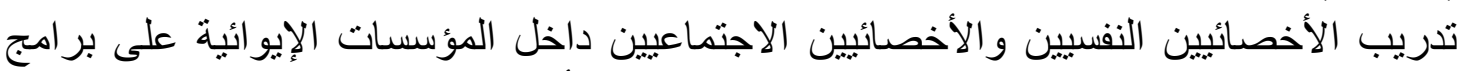

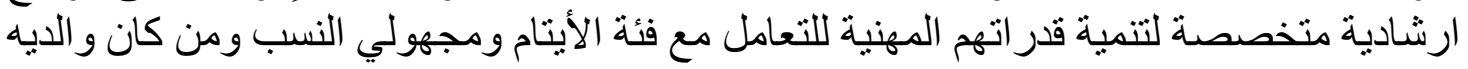

محبوسين. ضرورة الاهتمام بالتوجيه والإرشاد النفسي المستمر للأيتام ومجهولي النسب ومن كان والدية محبوسين في المؤسسات الإيو ائية.

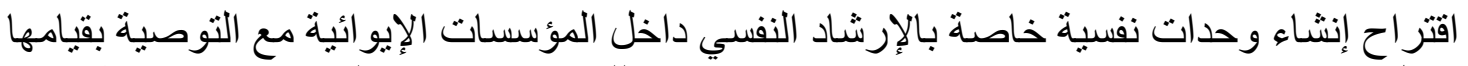

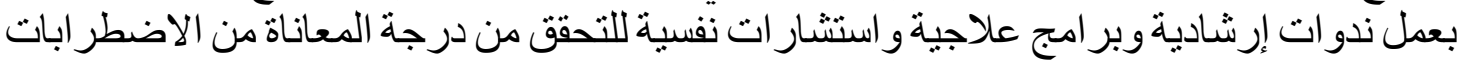

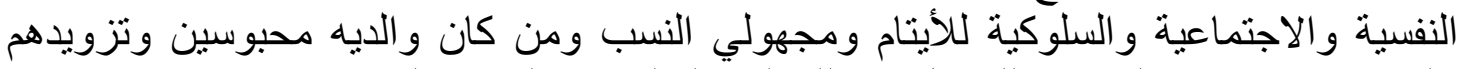

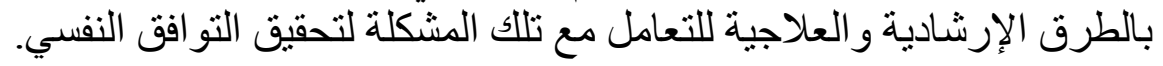

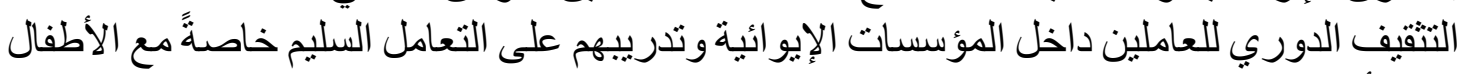

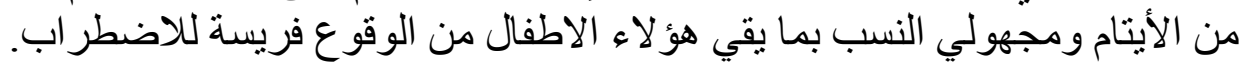

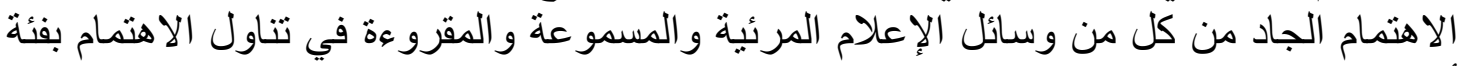
أطفال المؤسسات الإيو ائية. • إمداد المؤسسات الإيوائية بالبر امج النفسية والائة الاجتماعية و التعليمية للمقيمين بها.

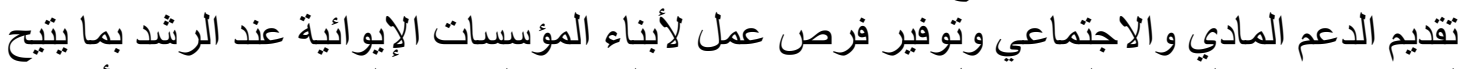

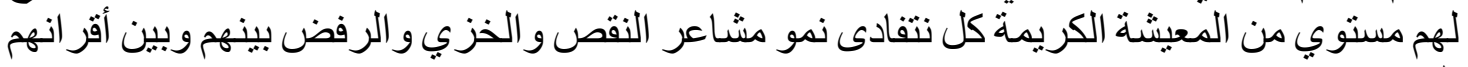
العاديين. در اسة سمات الثخصية توفر معلومات قد تساعد المعالجين على فهم الأسباب التي تدفع الأفر اد إلى إلى القيام بسلوك محدد، وكذلك قد يفيد في توقع أنماط معينة من السلوك في مو فو اقف معينة. 


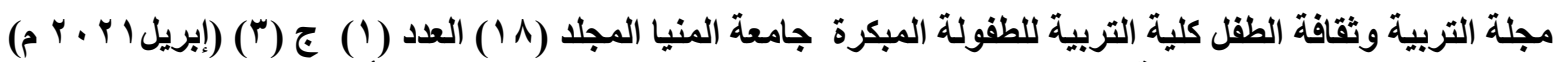

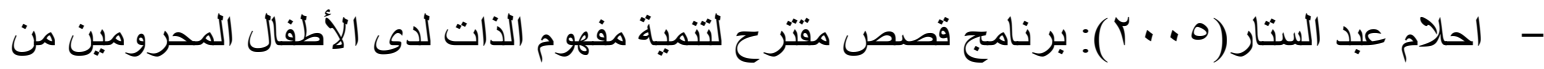

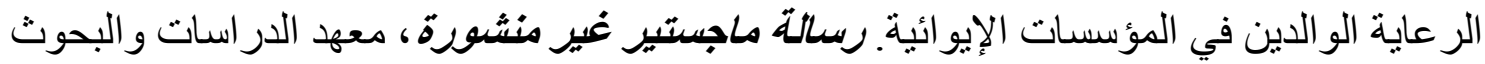

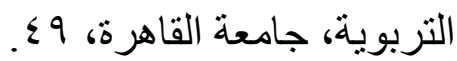

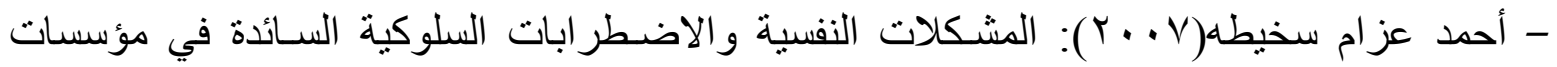

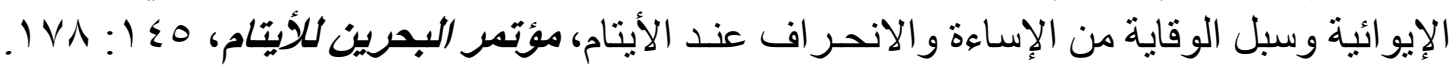

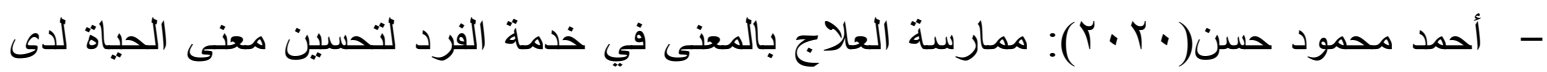

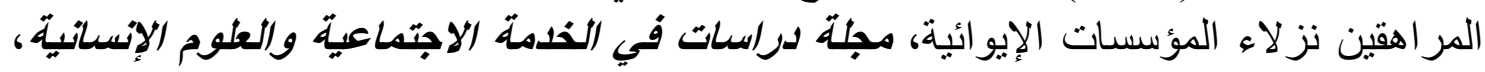

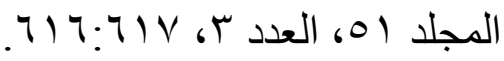

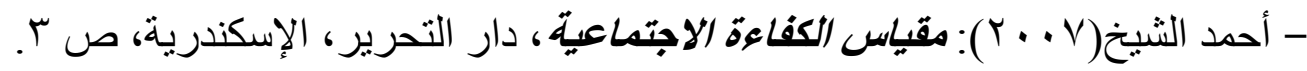

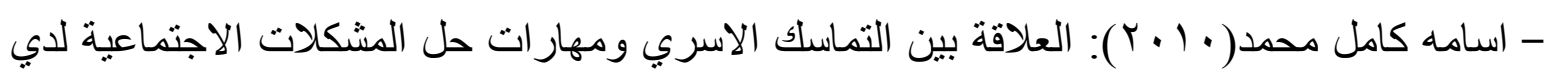

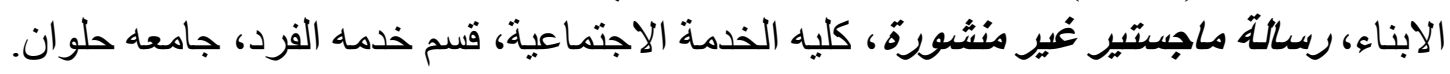

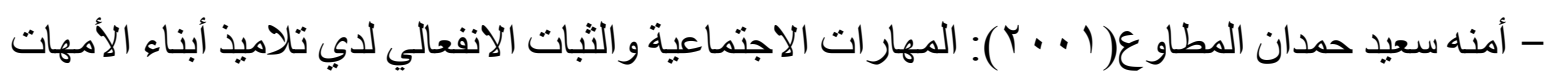

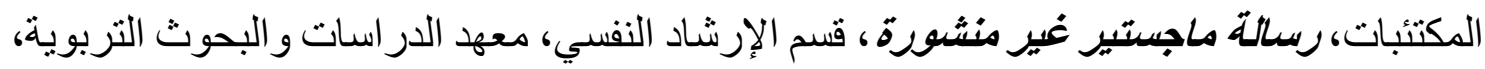
جامعه القاهرة.

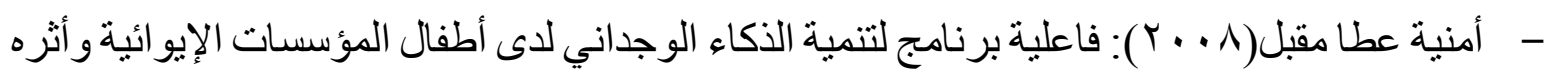

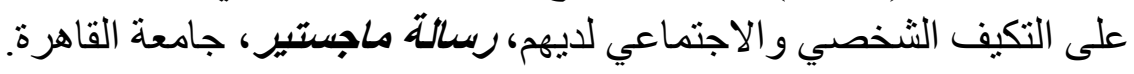

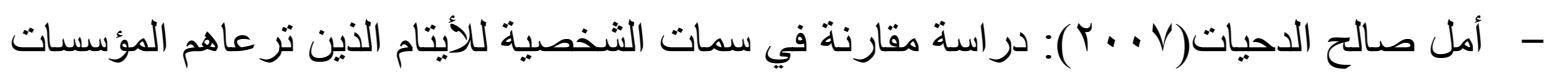

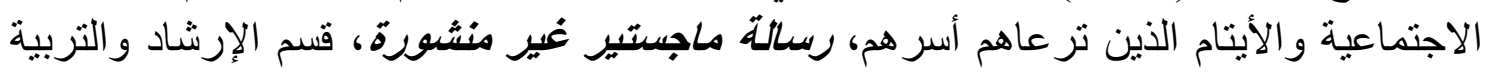
الخاصة، جامعة مؤته، الأردن.

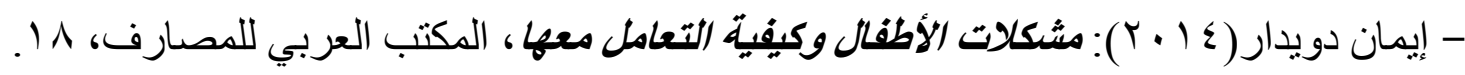

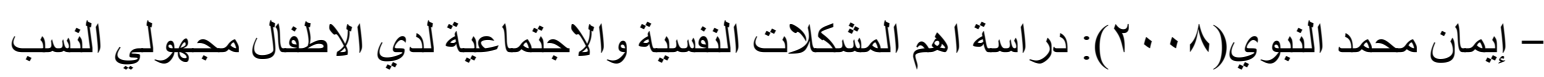

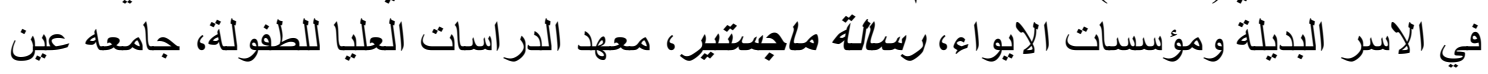

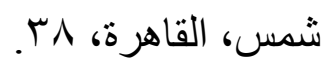
- بلعبد الطاهر الربغوثي(7 ( • Y): دور دار رعاية البنات في علاج الظروف الاجتماعية والاقتصادية

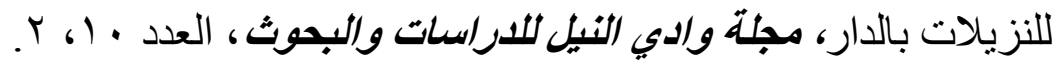




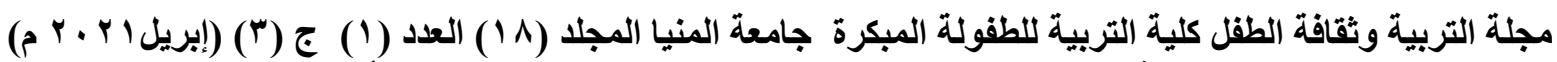

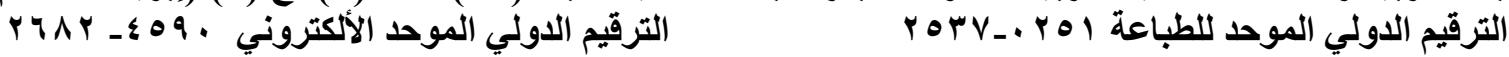

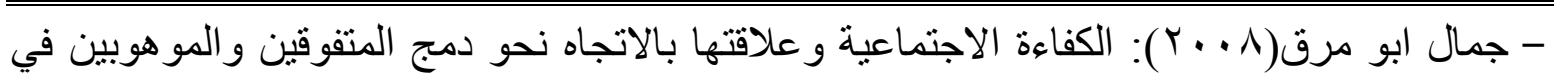

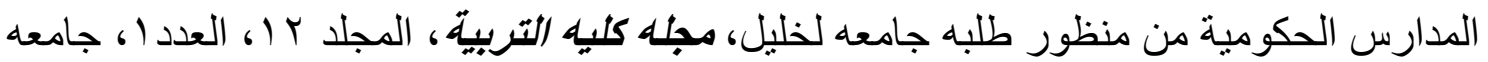

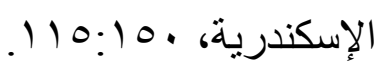

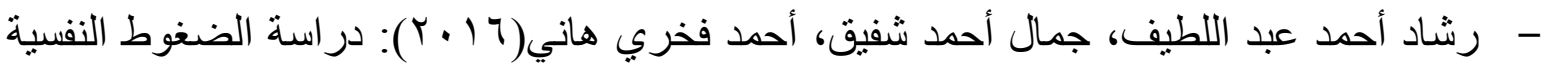

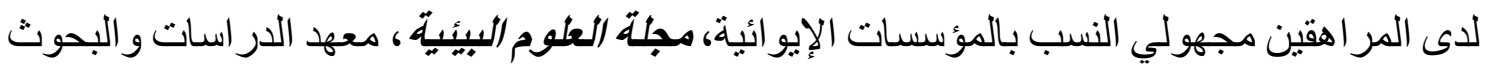

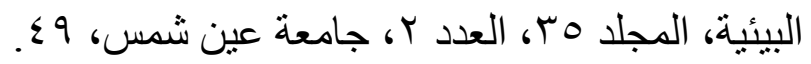

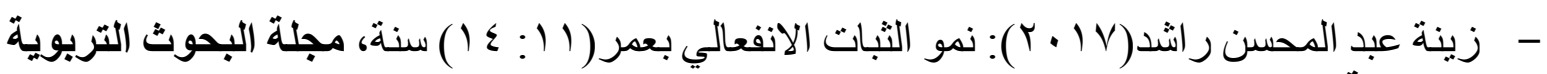

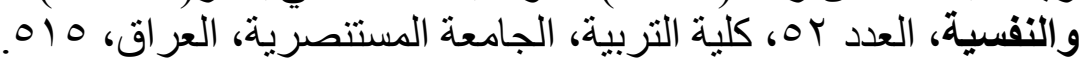

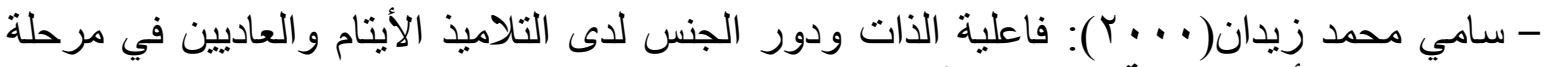

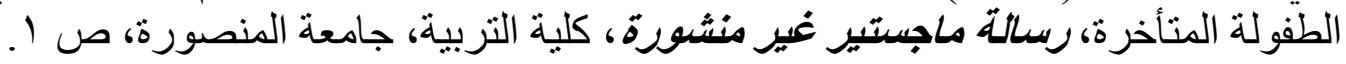

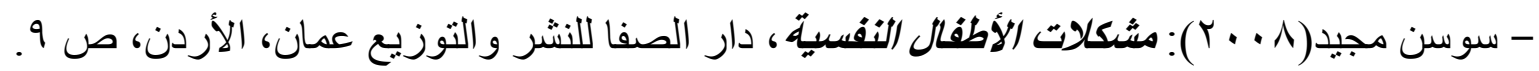

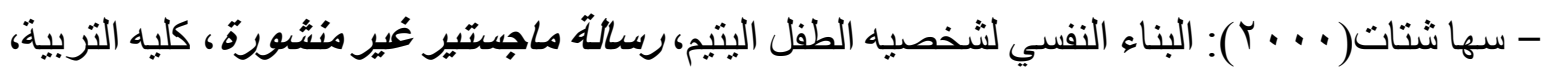

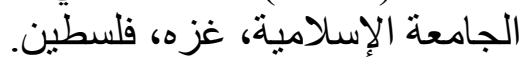

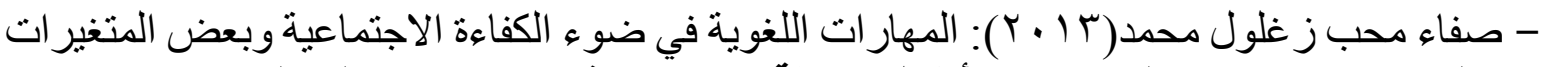

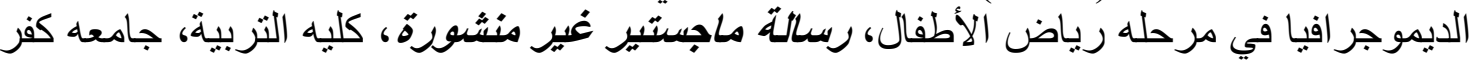
الثيخ.

- عادل عبد الله محمد( · . . ب): دراسات في الصحة النفسية(الهوية والاغتراب والاضطرابات النفسية)

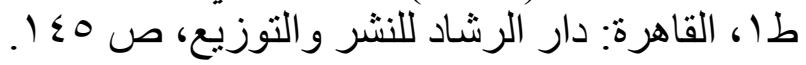

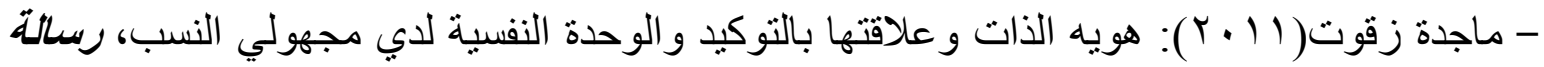

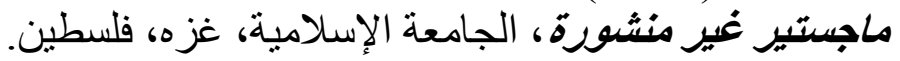

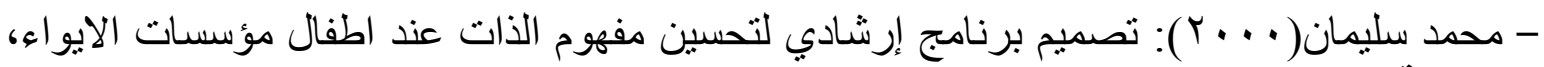

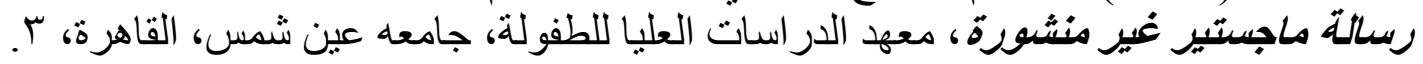

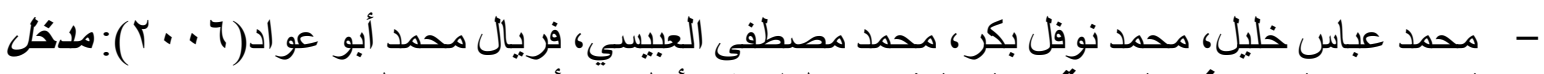

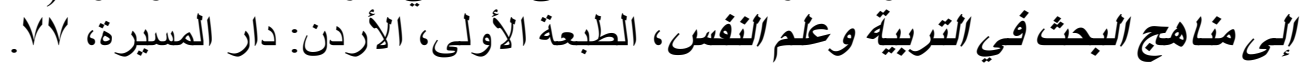

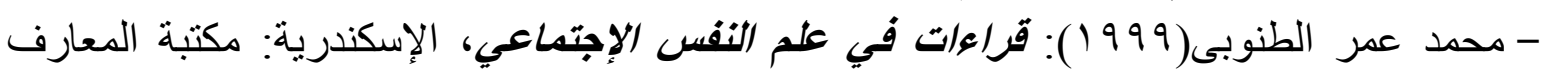

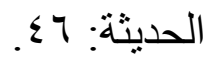

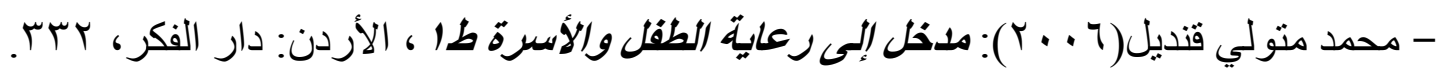

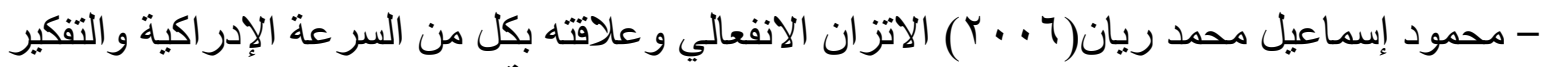

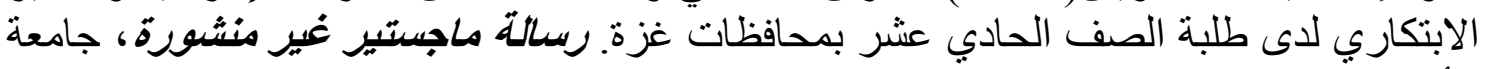

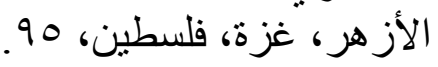
- مصطفى محمود مصطفي(10 1 ب ب): دور الممارسة العامة للخدمة الاجتماعية في تحقيق الأمن الإنساني

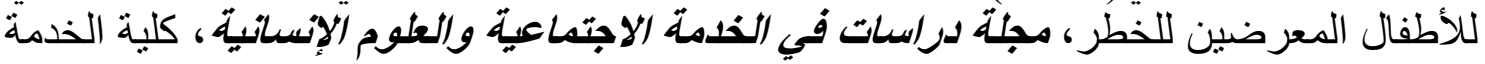

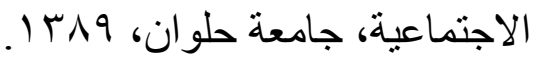




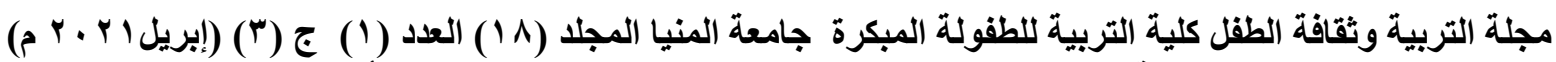

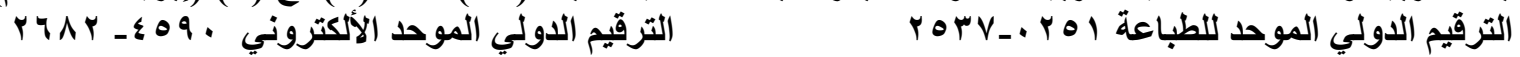

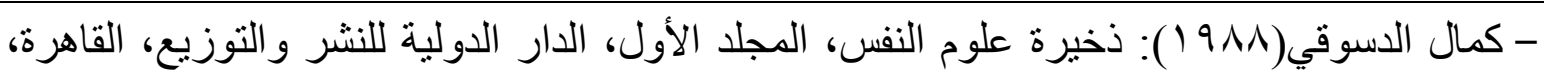
EVY

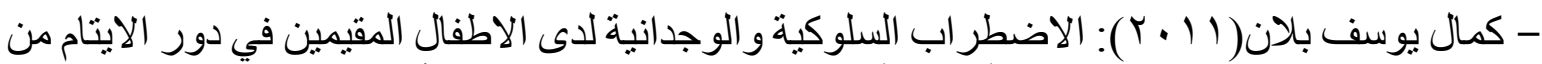

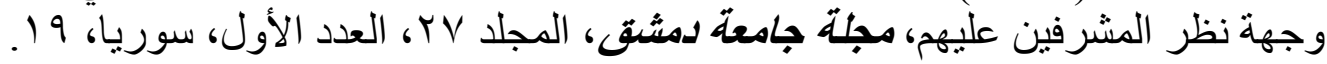

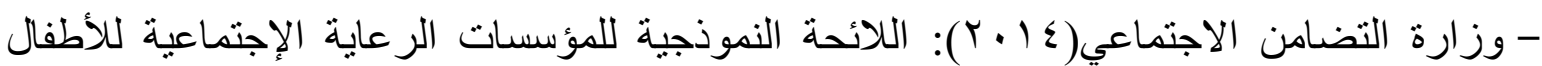

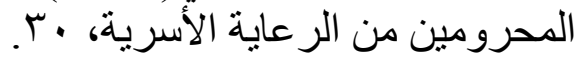

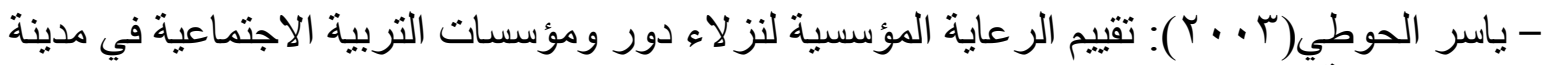
جدة، رسالة ماجستبير غير منشورة ، كلية العلوم الاجتماعية، جامعة الإمام محمد بن سعود الإسلامية، المملكة العربية السعودية. المراجع الأجنبية: العزية

- Abu-Ghazal, M.(2009). Child emotional and social development. Ministry of Culture Publication Series, Amman p: 15.

- Berrocal, P., \& Extremera, N.(2006). Emotional intelligence: A theoretical and empirical review of its first 15 years of history. Journal of Psicothema, 18, 7-12.

- Birknerova, Z., Frankovský, M., \& Zbihlejová, L.(2013). Social intelligence in the context of personality traits of teachers. American International Journal of Contemporary Research, 3(7), 11-17. Corpus ID: 26397511

- Bohman, M., \& Sigvardsson, S.(Y...). Long term effects of early institutional care: A prospective longitudinal study. Journal of Child Psychology and Psychiatry, 20(2), 111-117.

- Brown, D. Tramayne, s. Hoxha, D.\& Telander, K.(2018). Academic Performance and Persistence: Amete- 72(3), 298- 308.

- Foster, G. and Williamson, J. 2000. A review of Current Literature on the Impact of HIV/AIDS in Children Sub-Saharan Africa, vol. 14: 275-284

- Ibrahim, B.(2018). Effectiveness of a program to develop emotional intelligence and psychological adjustment among orphan child in early childhood. Arab Journal of Media and Child Culture, 4, 59-102.

- Majchrzyk, Z., \& Grzywińska-Aleksandrowicz, K.(2016). Personality Traits and Social Competence of The Offenders Against Children. Sveikatos mokslai/Health Sciences, 26(1), 96-104. DOI: 10.5200/sm-hs.2016.015.

- Risan, S. H.(2014). The reciprocal relationship between social competence and forms of aggression in children(Master's thesis, NTNU). Norwegian University of Science and Technology. 


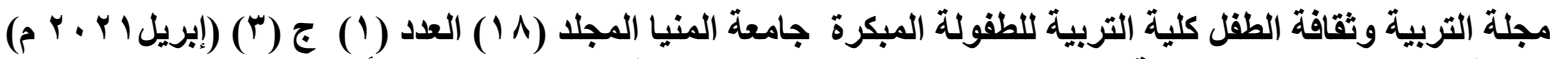

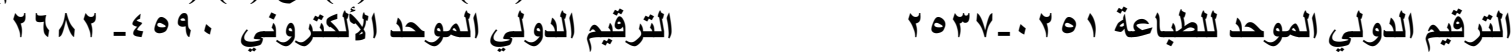

- Smółka, P., \& Szulawski, M.(2011). Personality traits and motivational traits as predictors of social competence. Implication for occupational selection process. Edukacja Ekonomistów i Menedżerów, 22(4), 111-126. DOI: $10.5604 / 01.3001 .0009 .5542$

- Suveg C, Zeman J.(2004) Emotion regulation in children with anxiety disorders, Journal of Clinical Child \& Adolescent Psychology 33(4):750-9

- Theie, S.(2007). The relationship between self-esteem and problem behaviour, social and academic competence. The American Educational Research Association Annual Meeting 2007. DOI: 10.2478/mjss-2018-0055

- Welsh, J.\& Bierman, K.(2003). Social competence. Gate Encyclopedia and Adolescence. 